\author{
OAK RIDGE
}

NATIONAL LABORATORY

MANAGED BY UT-BATTELLE

FOR THE DEPARTMENT OF ENERGY

\title{
Analytical Methods Development in Support of the Caustic Side Solvent Extraction System
}

\section{April 2001}

Prepared by

Michael P. Maskarinec, John E. Caton, Jr., and Thomas L. White

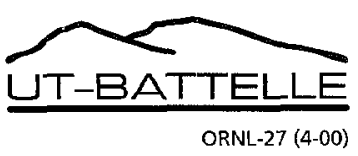




\title{
DOCUMENT AVAILABILITY
}

Reports produced after January 1, 1996, are generally available free via the U.S. Department of Energy (DOE) Information Bridge.

Web site $h$ ttp://www.osti.gov/bridge

Reports produced before January 1,1996 , may be purchased by members of the public from the following source.

\author{
National Technical Information Service \\ 5285 Port Royal Road \\ Springfield, VA 22161 \\ Telephone 703-605-6000 (1-800-553-6847) \\ TDD 703-487-4639 \\ Fax 703-605-6900 \\ E-mail info@ntis.fedworld.gov \\ Web site http://www.ntis.gov/support/ordernowabout.htm
}

Reports are available to DOE employees, DOE contractors, Energy Technology Data Exchange (ETDE) representatives, and International Nuclear Information System (INIS) representatives from the following source.

Office of Scientific and Technical Information

P.O. Box 62

Oak Ridge, TN 37831

Telephone 865-576-8401

Fax 865-576-5728

E-mail reports@adonis.osti.gov

Web site http://www.osti.gov/contact.html

This report was prepared as an account of work sponsored by an agency of the United States Government. Neither the United States Government nor any agency thereof, nor any of their employees, makes any warranty, express or implied, or assumes any legal liability or responsibility for the accuracy, completeness, or usefulness of any information, apparatus, product, or process disclosed, or represents that its use would not infringe privately owned rights. Reference herein to any specific commercial product, process, or service by trade name, trademark, manufacturer, or otherwise, does not necessarily constitute or imply its endorsement, recommendation, or favoring by the United States Government or any agency thereof. The views and opinions of authors expressed herein do not necessarily state or reflect those of the United States Government or any agency thereof. 


\section{Analytical Methods Development in Support of the Caustic Side Solvent Extraction System}

Authors

M. P. Maskarinec

Signature: $114 P$ MaLarude

Date: $4 / 26 / 01$

I. E. Caton, Ir.

signature: $1,0$. (etton $(m, 0, m)$ Date 4126101

T. L. White

signature: "Womas whote

Date: $04 / 24 / 01$

Approvals:

L. N. Klatt, CSSX Project Integration Manager

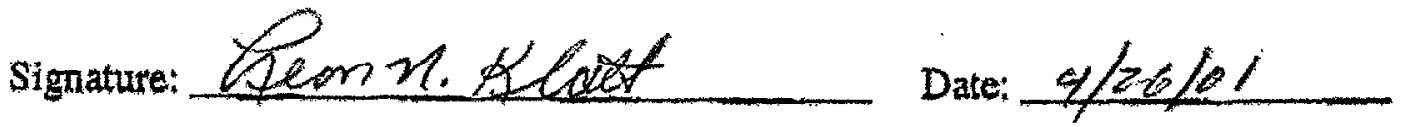

R. T. Jubin, Chemical and Energy Research Section Head

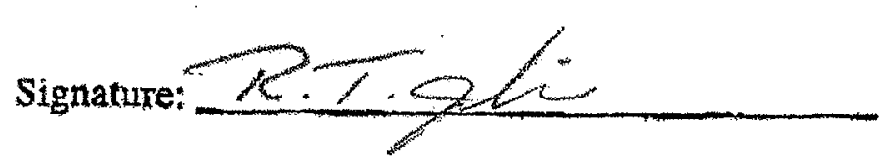

Date: $4 / 26 / 0$ 


\section{.}




\title{
Analytical Methods Development in Support of the Caustic Side Solvent Extraction System
}

\author{
Michael P. Maskarinec and John E. Caton, Jr. \\ Chemical and Analytical Sciences Division \\ Oak Ridge National Laboratory \\ Oak Ridge, TN 37830 \\ and \\ Thomas L. White \\ Westinghouse Savannah River Technology Center \\ Aiken, SC 29808
}

April, 2001

\begin{abstract}
The submitted manuscript has ben authored by a contractor of the U.S. Government under contract DE-AC05000 R22725. Accordingly, the U.S. Government retains a nonexclusive, royalty free license to publish or reproduce the published form of this contribution, or allow others to do so, for U.S. Government purposes.
\end{abstract}

Prepared for

the Office of Project Completion,

Office of Environmental Management, U.S. Department of Energy

and

the Tanks Focus Area, Office of Science and Technology,

Salt Processing Program, U.S. Department of Energy

Prepared by

OAK RIDGE NATIONAL LABORATORY

Oak Ridge, Tennessee 37831-6285

managed by

UT-Battelle, LLC

for the

U.S. DEPARTMENT OF ENERGY

under contract DE-AC05-00OR22725 


\section{Table of Contents}

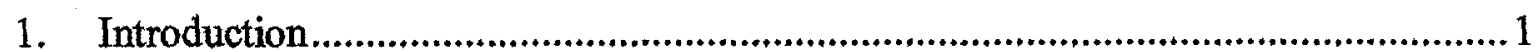

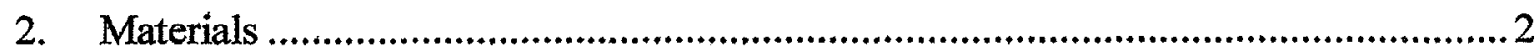

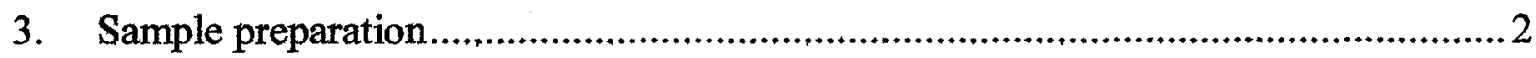

4. Analytical methods for solvent components...........................................................

4.1. Reverse-Phase HPLC...................................................................................... 4

4.2. Gel Permeation Chromatography method for quantitative and qualitative analysis

4.3. Analytical method for tri-n-octylamine (TOA) ................................................15

4.4. Extension of the analytical methods to possible breakdown products ................... 17

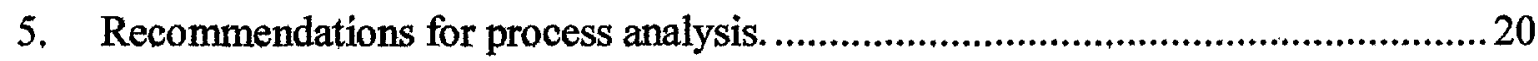

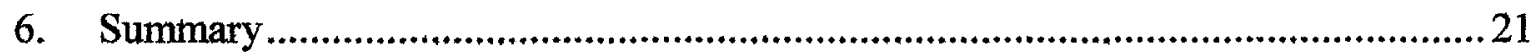

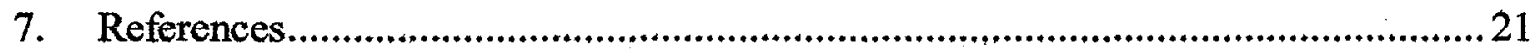

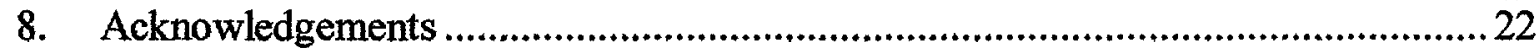

9. Appendix 1. Calibration data for reverse-phase HPLC method...............................23 


\section{List of Tables}

Table 1. Intra-day accuracy and precision............................................................... 10

Table 2. Linearity of the GPC method for the test compounds ........................................ 13 


\section{List of Figures}

Figure 1. Apparatus used for the extraction of aqueous samples. .....................................

Figure 2. Reverse phase liquid chromatogram of standard components $(50 \mathrm{mg} / \mathrm{L})$.......... 4

Figure 3. Multi-wavelength analysis of pristine solvent system. ……..............................5

Figure 4. Calibration curve for 4-sec-butylphenol at $226 \mathrm{~nm}$. .......................................6

Figure 5. Calibration curve for 4-sec-butylphenol at $205 \mathrm{~nm}$. .......................................6

Figure 6. Calibration curve for 4-sec-butylphenol at $254 \mathrm{~nm}$......................................

Figure 7. Calibration curve for Cs-7SB at $226 \mathrm{~nm}$.................................................. 7

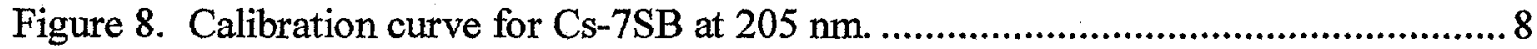

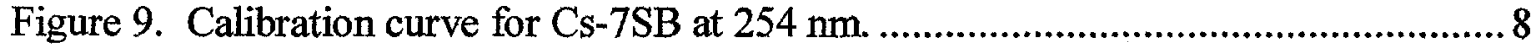

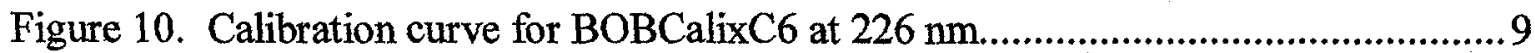

Figure 11. Calibration curve for BOBCalixC6 at $205 \mathrm{~nm}$............................................9

Figure 12. GPC analysis of the solvent system. Top chromatogram is from the ELD. Bottom chromatogram is from the UV absorbance detector. The peak at 5.6 minutes is BOBCalixC6, and the peak at 6.7 minutes is the modifier. .......... 11

Figure 13. Plot of molecular weight of polystyrene standards versus elution volume The high molecular weight compounds elute earlier.

Figure 14. Calibration curve for BOBCalixC6 at $280 \mathrm{~nm}$............................................. 13

Figure 15. Calibration curve for Cs-7SB at $280 \mathrm{~nm}$............................................... 14

Figure 16. Calibration curve for 4-sec-butylphenol at $280 \mathrm{~nm}$. ..................................... 14

Figure 17. Gas chromatographic analysis of pristine solvent system for tri-n-octylamine (retention time of 25.447 minutes).

Figure 18. Results of standard addition of tri-n-octylamine to pristine solvent sample. . 16

Figure 19. Mass chromatogram of 4-sec-butylphenol (15 minutes), and tri-n-octylamine (28 minutes)

Figure 20. Chromatogram of the expected thermal breakdown products of tri-noctylamine.

Figure 21. Analysis of the solvent system prior to thermal treatment using a nitrogenselective detector.

Figure 22. Analysis of thermally degraded sample. 


\section{Executive Summary}

The goal of the project reported herein was to develop and apply methods for the analysis of the major components of the solvent system used in the Caustic-Side Solvent Extraction Process (CSSX). These include the calix(4)arene, the modifier, 1-(2,2,3,3tetrafluoropropoxy)-3-(4-sec-butylphenoxy)-2-propanol and tri-n-octylamine. In addition, it was an objective to develop methods that would allow visualization of other components under process conditions. These analyses would include quantitative laboratory methods for each of the components, quantitative analysis of expected breakdown products (4-sec-butylphenol and di-n-octylamine), and qualitative investigations of possible additional breakdown products under a variety of process extremes. These methods would also provide a framework for process analysis should a pilot facility be developed.

Two methods were implemented for sample preparation of aqueous phases. The first involves solid-phase extraction and produces quantitative recovery of the solvent components and degradation products from the various aqueous streams. This method can be automated and is suitable for use in radiation shielded facilities. The second is a variation of an established EPA liquid-liquid extraction procedure. This method is also quantitative and results in a final extract amenable to virtually any instrumental analysis.

Two HPLC methods were developed for quantitative analysis. The first is a reverse-phase system with variable wavelength UV detection. This method is excellent from a quantitative point of view. The second method is a size-exclusion method coupled with dual UV and evaporative light scattering detectors. This method is much faster than the reverse-phase method and allows for qualitative analysis of other components of the waste. For tri-n-octylamine and other degradation products, a GC method was developed and subsequently extended to GC/MS. All methods have precision better than $5 \%$. The combination of these methods allows both quantitative analysis of the major solvent components and visualization of any minor components, including breakdown products. 


\section{Introduction}

One of the separation processes under investigation by the DOE Tank Focus Area is a calix[4]arene based solvent system developed at Oak Ridge National Laboratory for the removal of cesium from highly alkaline radioactive waste. The final product stream is a highly concentrated, weakly acidic cesium solution suitable for encapsulation in glass (vitrification). There are four components in the solvent system:

- Calix[4]arene-bis(t-octylbenzo-crown-6); "BOBCalixC6"; 11,500 mg/L, 0.01 molar,

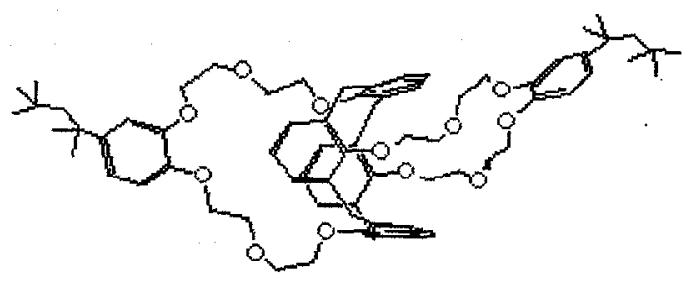

- 1-(2,2,3,3-tetrafluoropropoxy)-3-(4-sec-butylphenoxy)-2-propanol; "Modifier"; $186,000 \mathrm{mg} / \mathrm{L}, 0.5 \mathrm{molar}$,

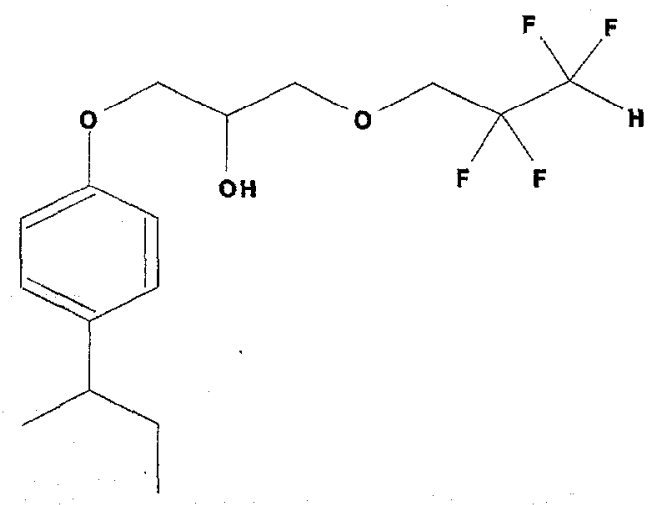

- Tri-n-octylamine; TOA; $354 \mathrm{mg} / \mathrm{L}, 0.001 \mathrm{molar}$, and

- ISOPAR® L diluent.

The goal of the project reported herein was to develop and apply methods for the analysis of these and other components (excluding the ISOPAR $@ L$ ) under process conditions. These analyses would include quantitative laboratory methods for each of the components, quantitative analysis of expected breakdown products (4-sec-butylphenol and dioctylamine), and qualitative investigations of possible additional breakdown products under a variety of process extremes. These methods would also provide a framework for process analysis should a pilot process facility be developed.

The analytical methods necessary for attaining project goals fell into two categories. First, it was necessary to develop methods for precise and accurate quantitative measurement of the three main components of the solvent: the calixarene, the modifier, and the TOA. Second, it was necessary to develop methods for the identification and 
semi-quantitative analysis of a range of potential decomposition by-products in the solvent. In addition, there was a need to be able to examine, at least qualitatively, the samples for minor components entering the process though the simulant and/or the real waste feed. Three matrices were involved, the solvent, the simulant, and the strip/scrub solutions. The strip solution is a dilute nitric acid solution $(0.001 \mathrm{M})$. These solutions are an integral part of the process cycle. In addition, consideration was given to the future necds for analysis of radioactive samples including process analysis in the proposed plant. While recognizing that the real waste may involve a changing matrix, the reported methods were developed with matrices matched as closely as possible to the expected waste streams.

\section{Materials}

All solvents used were HPLC grade or better (isopropanol, water, chloroform). Analytical standards were prepared gravimetrically in the appropriate solvent and further diluted prior to use. All pure compounds were acquired from the Chemical Separations Group, Chemical \& Analytical Sciences Division, Oak Ridge National Laboratory and used as received. For all gas chromatographic analyses, the carrier gas was ultra-highpurity helium.

\section{Sample preparation}

The primary sample matrices were the solvent itself and the aqueous samples resulting from the process. Sample preparation of the solvent samples involved a simple dilution with isopropanol. Isopropanol and chloroform were considered as diluents. Isopropanol was selected based on its more limited volatility, excellent solubility properties relative to the main components, and applicability to a range of instrumental analyses. Further, this solvent is relatively benign environmentally, and will not generate a mixed waste. When solvent samples, which had been in contact with acidic aqueous streams were analyzed for tri-n-octylamine, $1 \%$ triethylamine was added to the diluent. This was done to neutralize any residual acid in the solvent. Residual acid was found to decrease the response factor for tri-n-octylamine in the final measurement. Excess triethylamine has the capability to make the instrumental system basic, preventing nonspecific adsorption of organic bases (tri-n-octylamine, dioctylamine)

Preparation of the various aqueous samples (simulant, scrub, and strip solutions) was carried out using Oasis solid phase extraction cartridges (Waters Associates, Milford Ma.). A known volume of aqueous sample is applied to the cartridge, which is capable of extracting a broad range of organic compounds. The cartridge is then eluted with isopropanol, and the extract is suitable for further characterization. The apparatus used for this method is shown in Figure 1. These cartridges are convenient, require no pretreatment, and minimize exposure to radioactive samples. Recovery of the components of the pristine solvent system was quantitative using this methodology. 


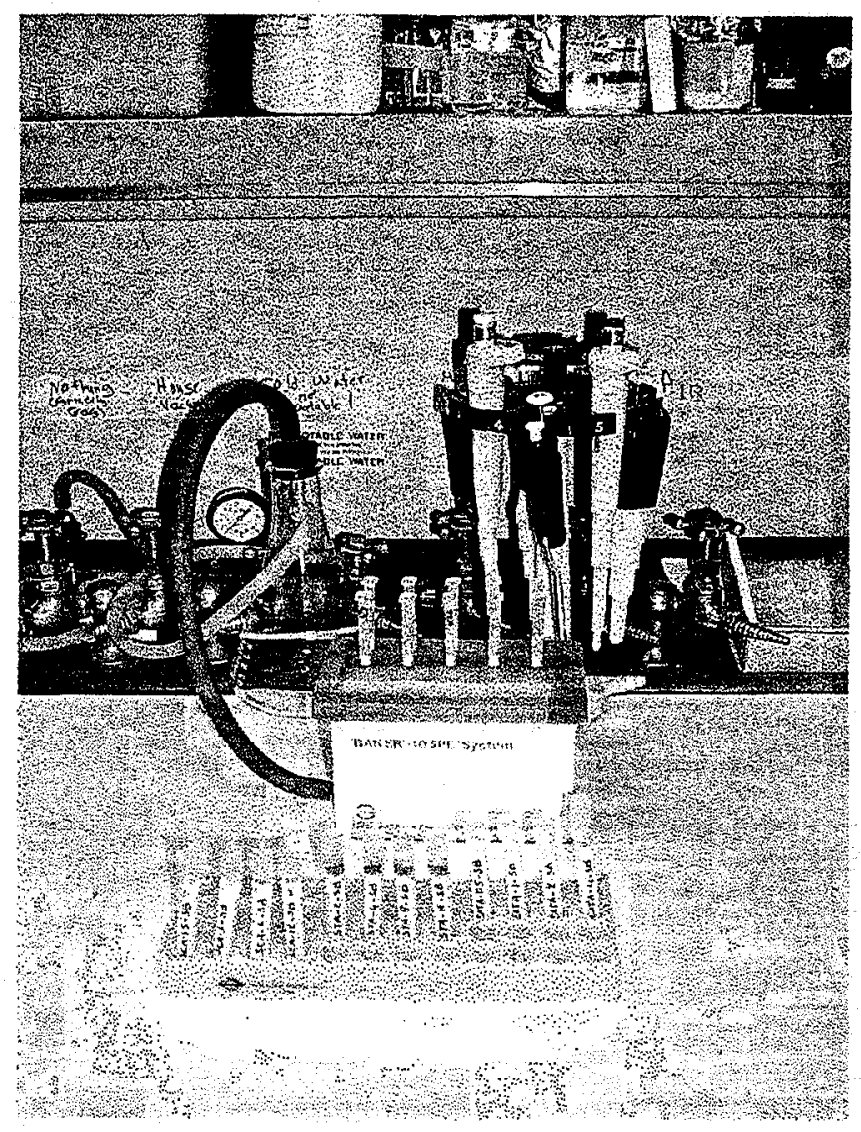

Figure 1. Apparatus used for the extraction of aqueous samples.

A slight vacuum is used to facilitate flow through the cartridges, which are shown inserted into a Baker extraction manifold. In normal operation, a 5-10 mL sample is passed through the cartridge, and then eluted with 1-2 $\mathrm{mL}$ isopropanol.

Preparation of aqueous samples resulting from partition studies was carried out using a variation of EPA Method 1310. This is a liquid/liquid extraction method carried out in a separatory funnel. For these experiments, the $\mathrm{pH}$ was adjusted to assure that the target analytes would be in the neutral form, and the extraction was carried out three times using methylene chloride as the solvent. The methylene chloride was evaporated down in a modified Kuderna-Danish evaporator, and the residue redissolved in isopropanol prior to analysis. Recovery of the target analytes was quantitative using this methodology. 


\section{Analytical methods for solvent components}

\subsection{Reverse-Phase HPLC}

For the purpose of solvent constituent analysis, specifically the calixarene and the modifier, two HPLC methods were developed and employed. Both used a HewlettPackard Model 1090 HPLC equipped with an autosampler and a diode array detector (UV absorbance). The first was an adaptation of an existing method from Savannah River Technology Center (SRTC) ${ }^{1}$, which employed a highly loaded reverse phase (RP) column with an isopropano1/water mobile phase. As implemented at ORNL, the method used a $250 \mathrm{~mm}$ Chemcosorb-5ODS UH column, $3.2 \mathrm{~mm}$ diameter (Phenomenex). The solvents were A: $99 / 1$ water/isopropanol and B: isopropanol. The initial mobile phase was $69.7 \% \mathrm{~B}$ and $30.3 \% \mathrm{~A}$ with a flow rate of $0.25 \mathrm{~mL} / \mathrm{min}$. The total run time was 35 min with a post-run equilibration time of $7 \mathrm{~min}$. Temperature was $45^{\circ} \mathrm{C}$. Under these conditions, good separation was achieved between the calixarene, modifier, and 4-secbutylphenol, which was expected to be a by-product of modifier degradation. An example of the chromatography of authentic standards is shown in Figure 2. The retention time of 4-sec-butylphenol is 7.491 minutes, that of the modifier is 8.626 minutes, and the calixarene 30.995 minutes. In this case, detection was by UV absorbance at $226 \mathrm{~nm}$.

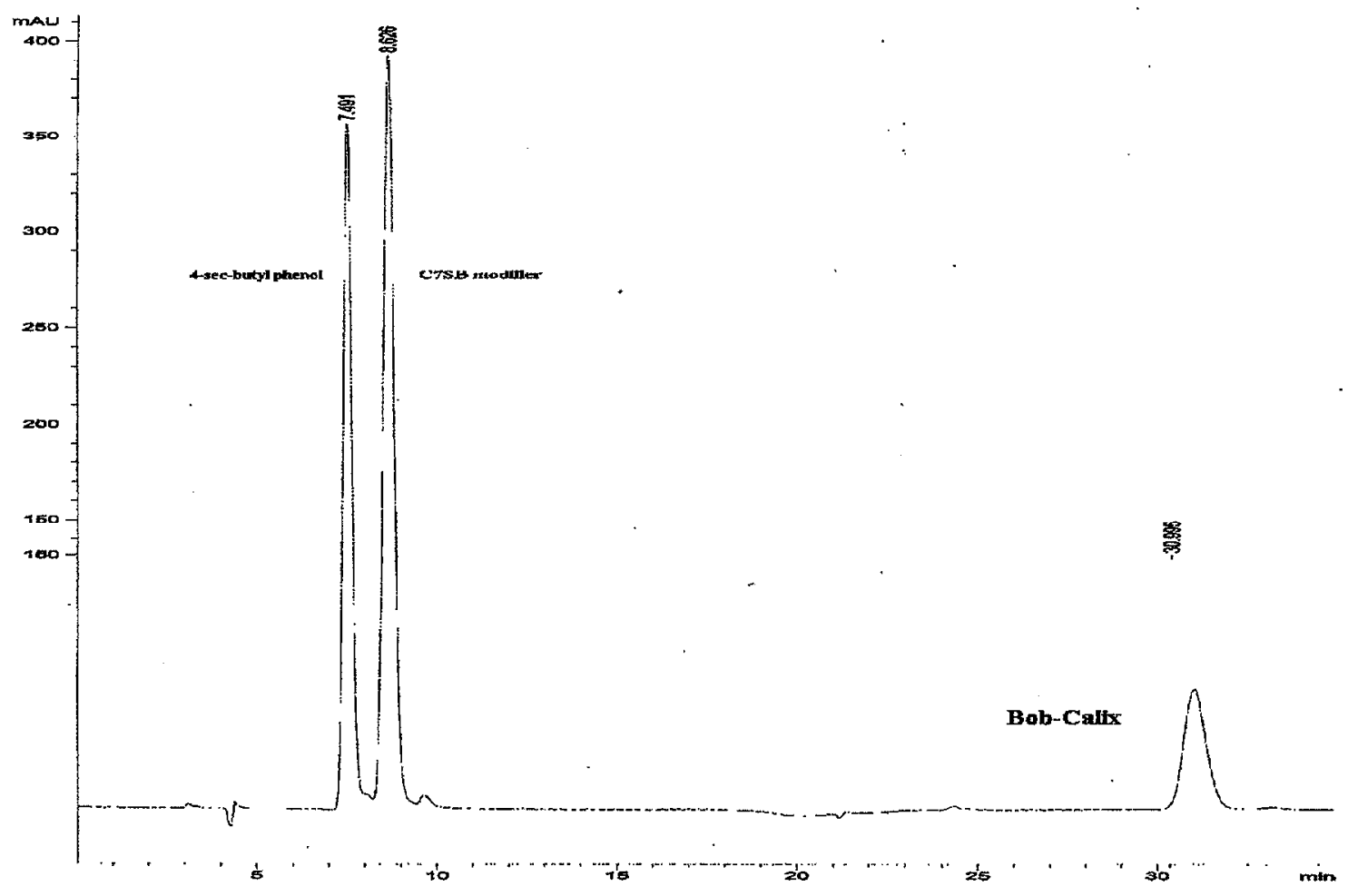

Figure 2. Reverse phase liquid chromatogram of standard components $(50 \mathrm{mg} / \mathrm{L})$. 
Advantages of this method include the ability to elute a broad range of organic compounds, good sensitivity for the target analytes, and excellent quantitative properties. Disadvantages include the inability to detect non-UV-absorbing compounds (e.g., TOA), and relatively long analysis time, perhaps making this method unsuitable for process analysis. An example of the analysis of the pristine solvent system at three wavelengths is in Figure 3. This method was found to be very sound for quantitative analysis as well. Example calibration curves for the method at various wavelengths are shown in Figure 4 through Figure 11.
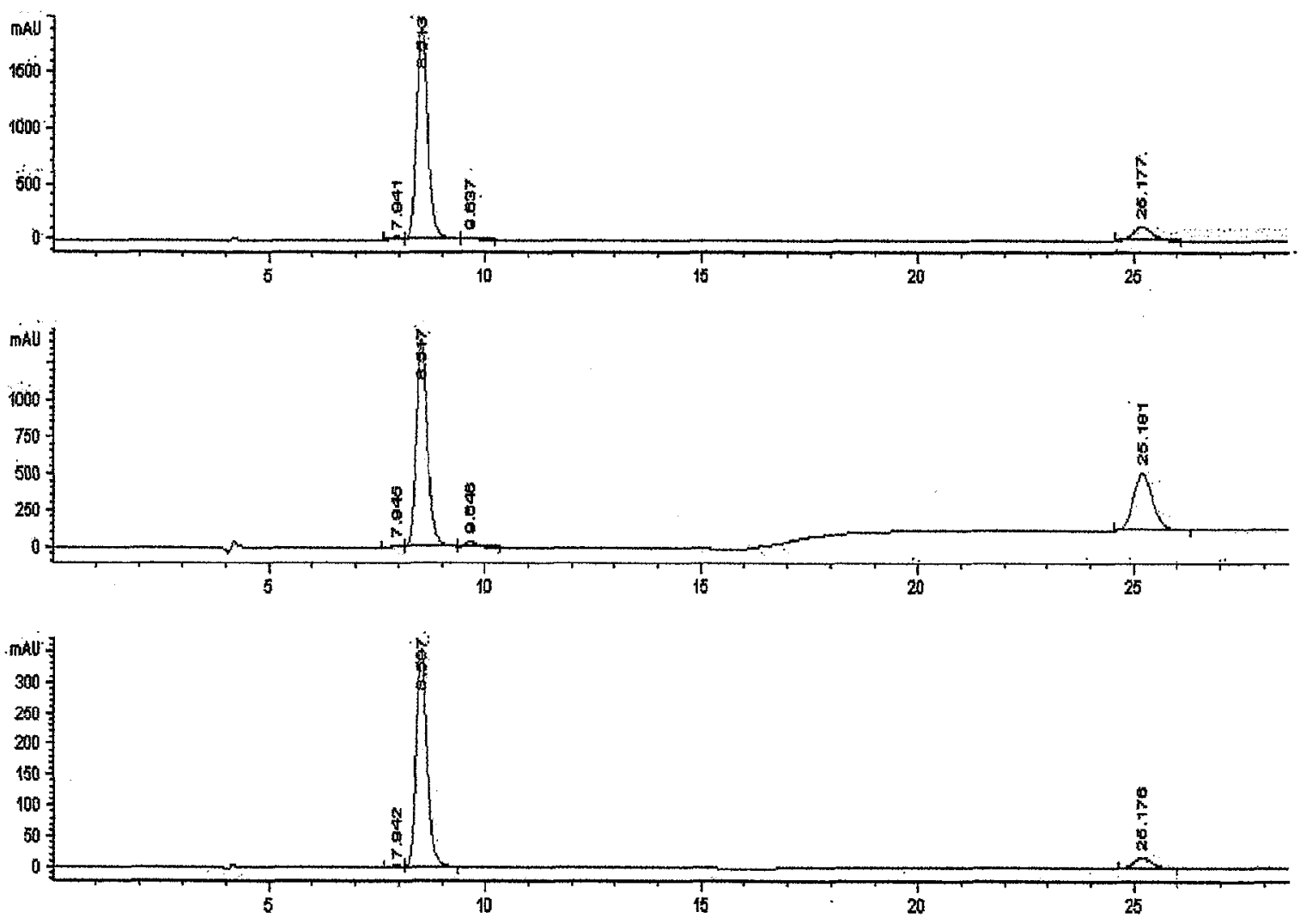

Figure 3. Multi-wavelength analysis of pristine solvent system. 


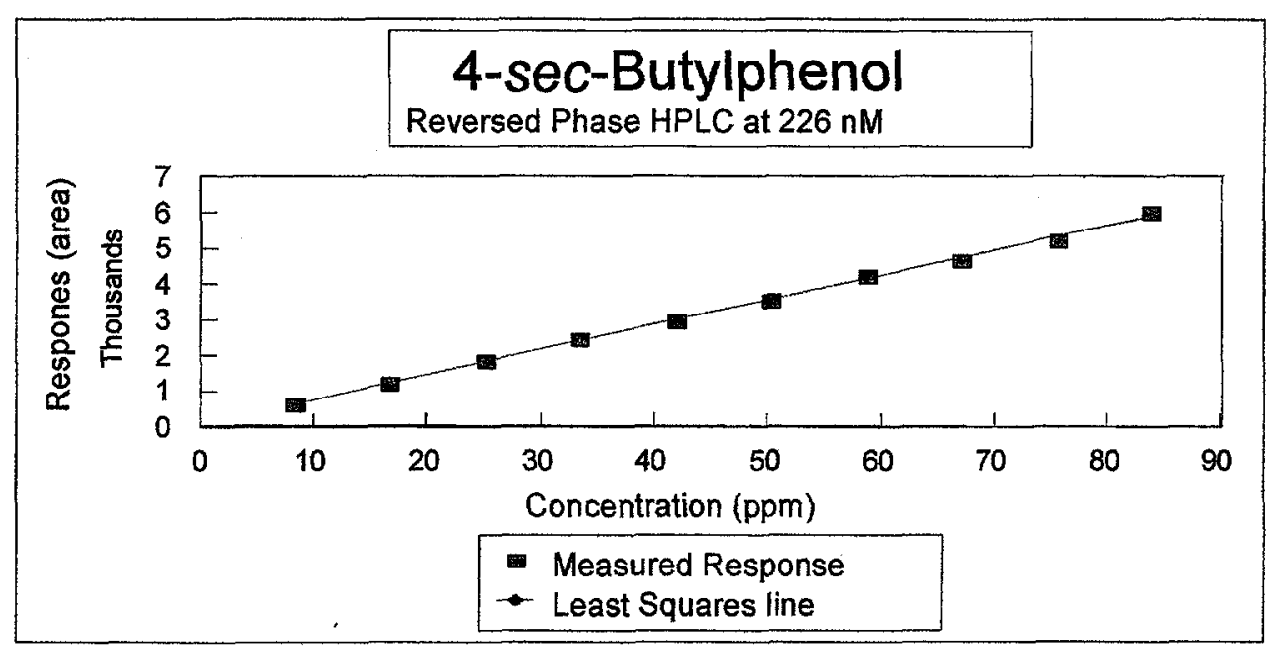

Figure 4. Calibration curve for 4-sec-butylphenol at $226 \mathrm{~nm}$.

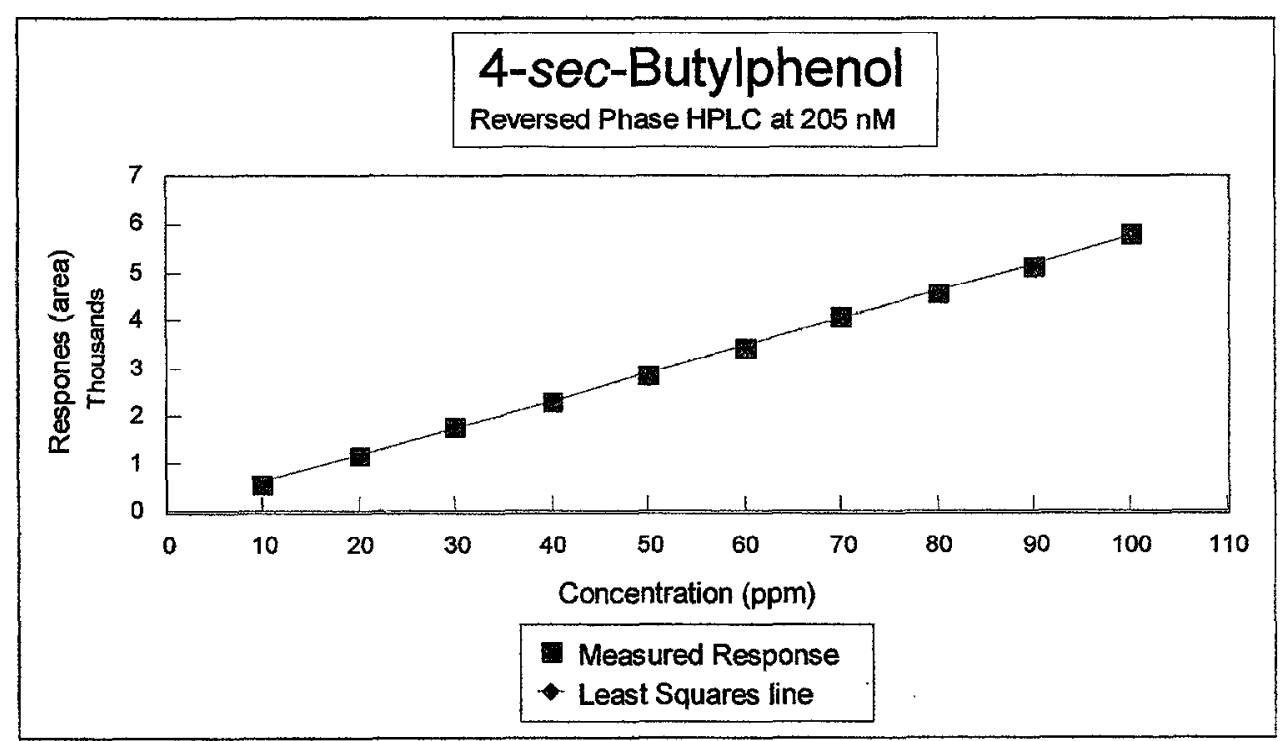

Figure 5. Calibration curve for 4-sec-butylphenol at $205 \mathrm{~nm}$. 


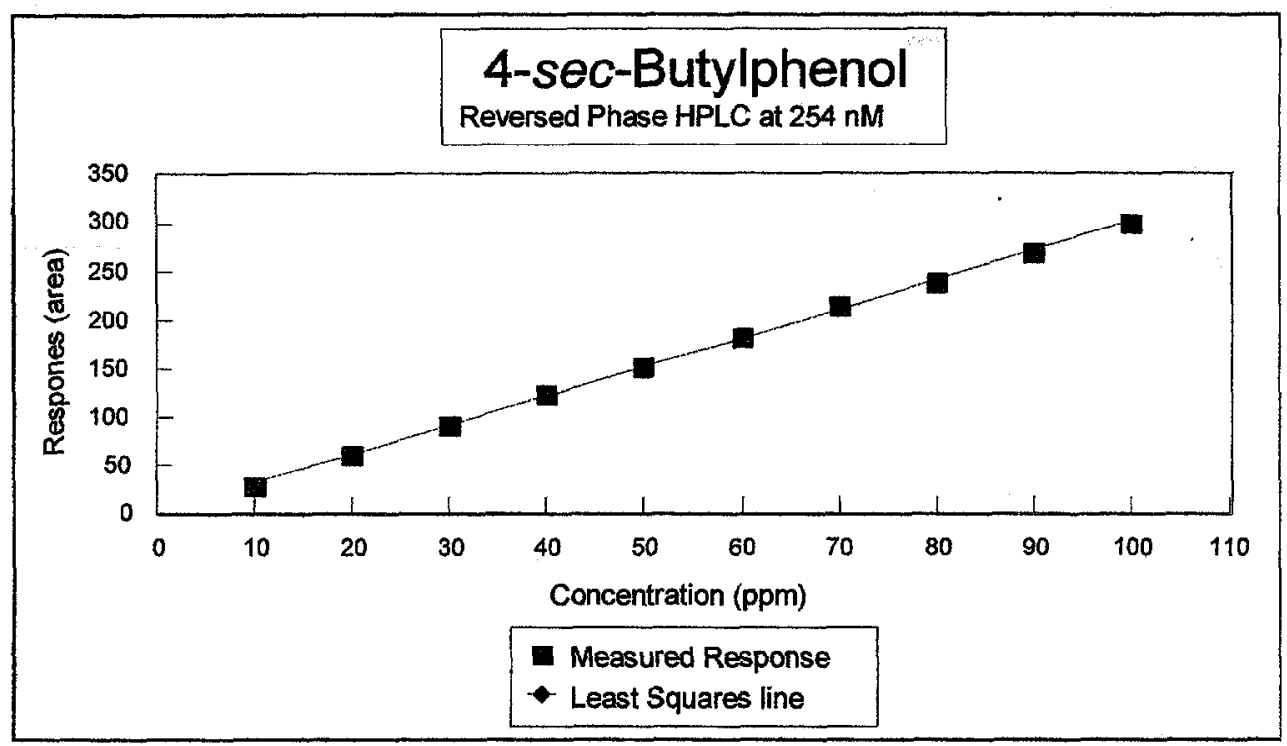

Figure 6. Calibration curve for 4-sec-butylphenol at $254 \mathrm{~nm}$.

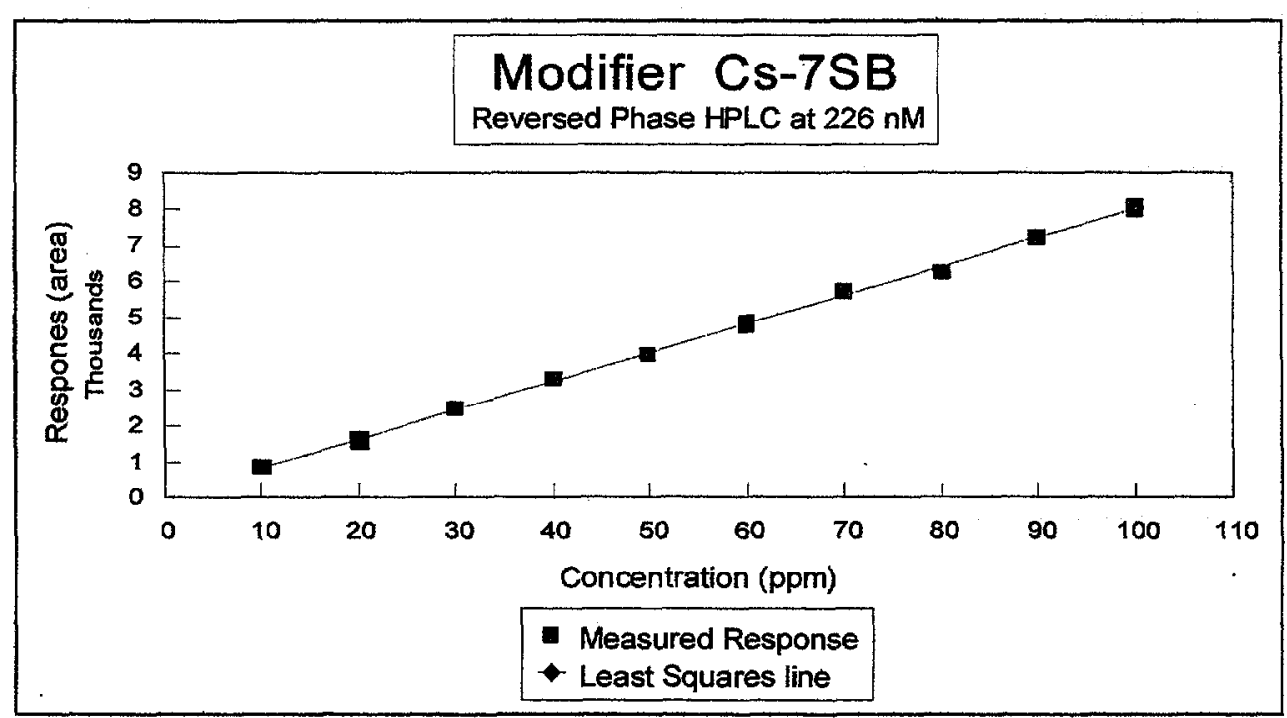

Figure 7. Calibration curve for Cs-7SB at $226 \mathrm{~nm}$. 


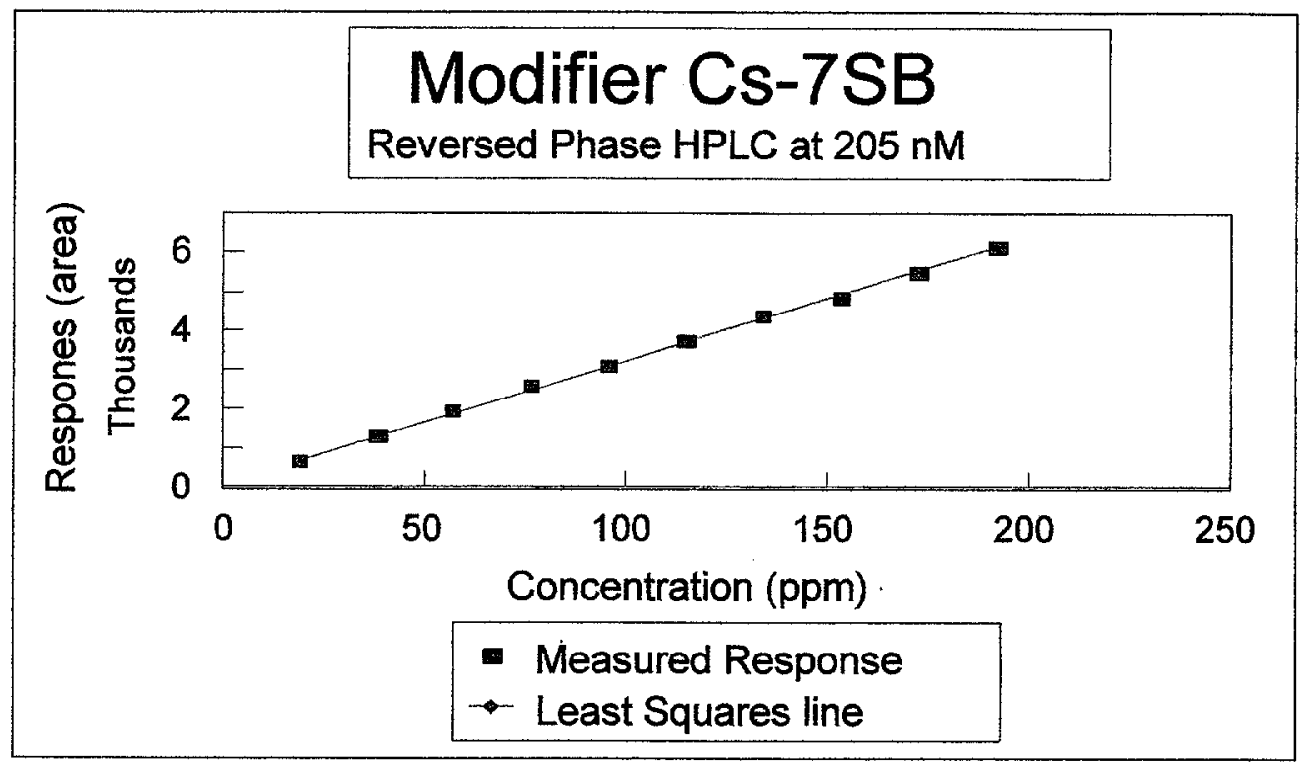

Figure 8. Calibration curve for Cs-7SB at $205 \mathrm{~nm}$.

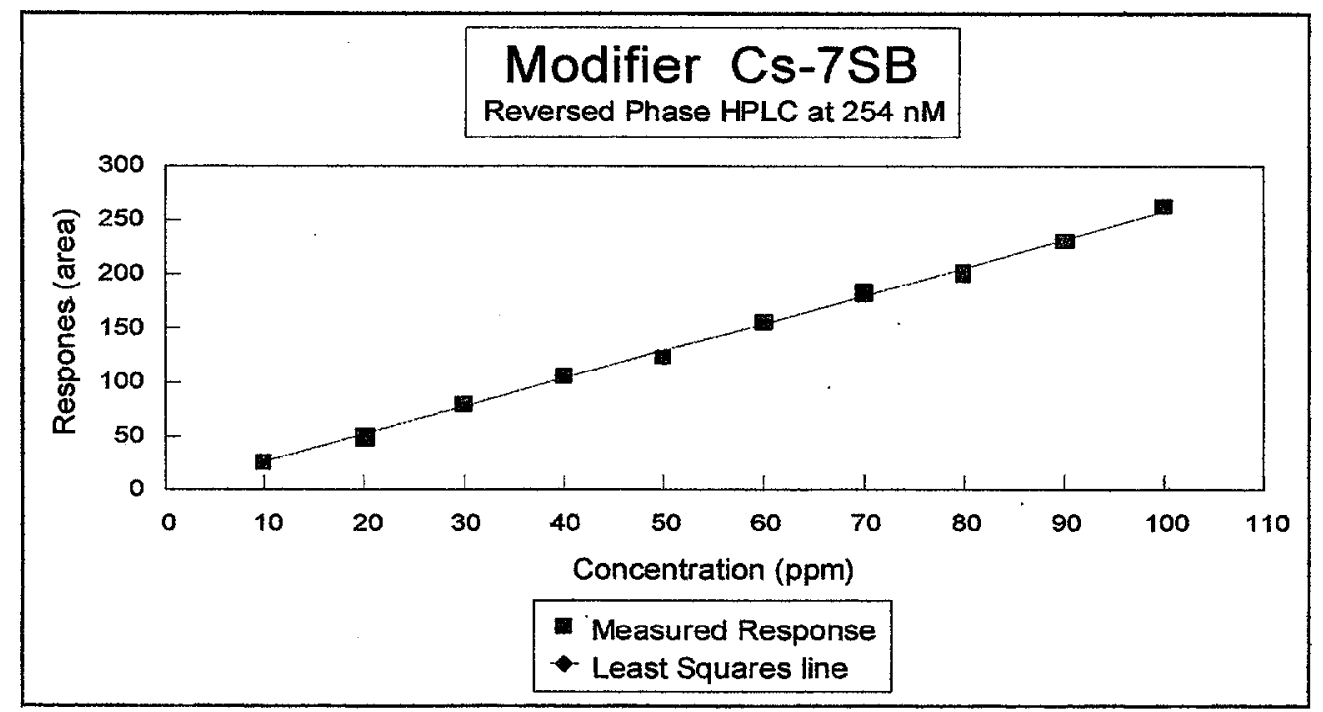

Figure 9. Calibration curve for Cs-7SB at $254 \mathrm{~nm}$. 


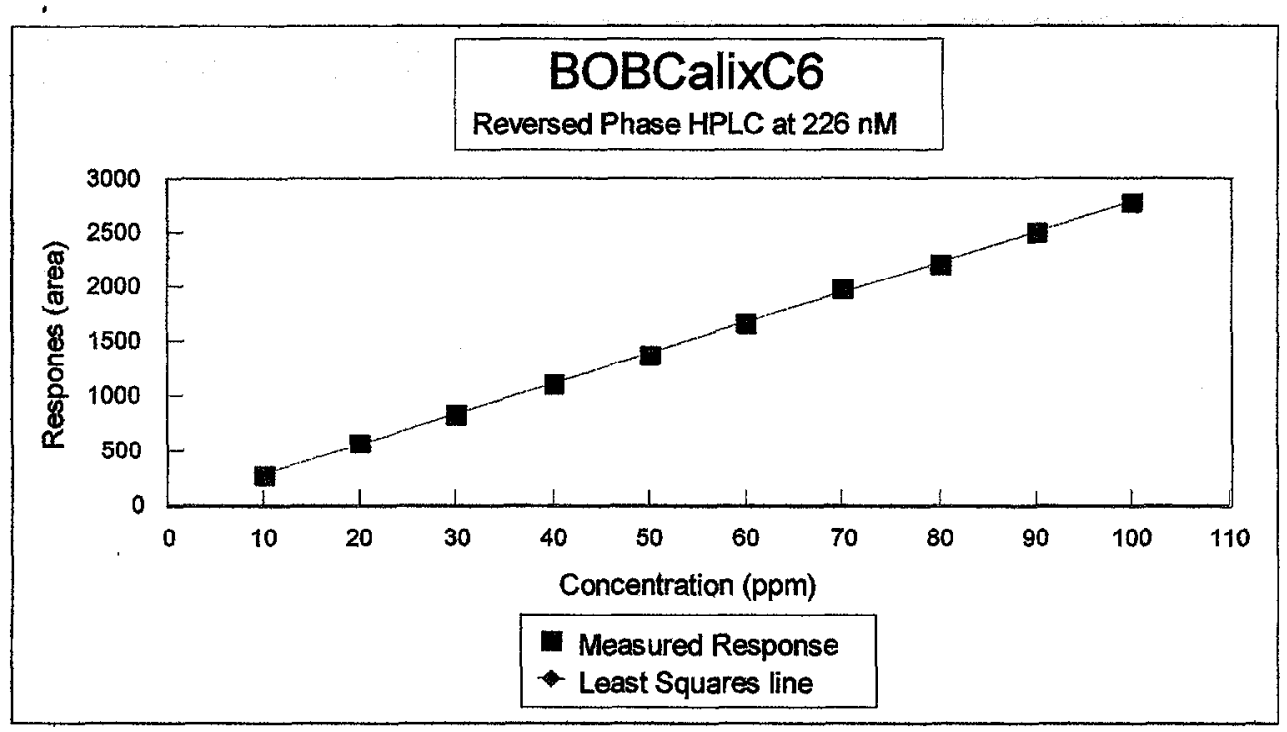

Figure 10. Calibration curve for BOBCalixC6 at $226 \mathrm{~nm}$.

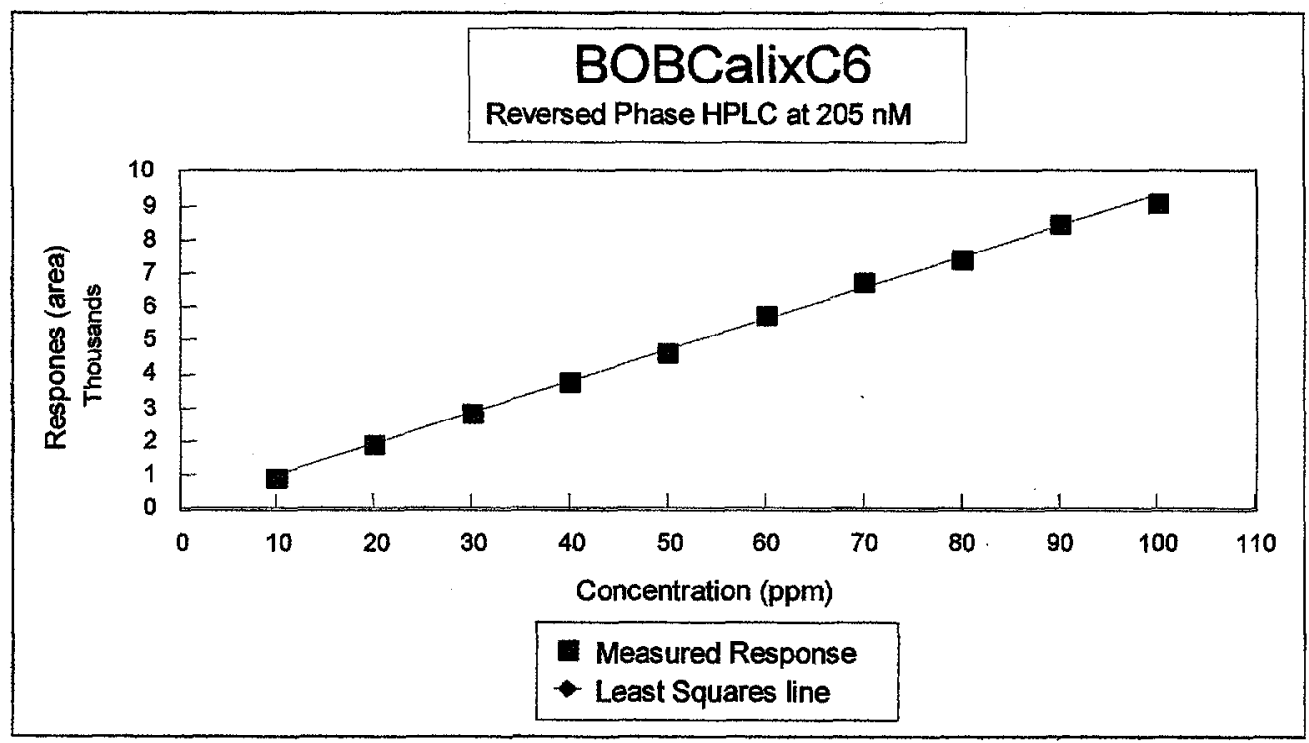

Figure 11. Calibration curve for BOBCalixC6 at $205 \mathrm{~nm}$. 
The linearity and fit are excellent in all of these plots. All raw data, including calculations, is given in Appendix 1. Unless otherwise noted, all quantitative data contained in this report for these three compounds was generated using this method. The variety of wavelengths improves the accuracy of the analysis by allowing for multiple response factors and minimizing the possibility of interferences. Day to day accuracy and precision data are given in Table 1.

Table 1. Intra-day accuracy and precision

\begin{tabular}{cccc}
\hline Analyte & Known Conc. (mg/L) & Measured Conc. (mg/L) & \% RSD \\
\hline 4-sec-butylphenol & & & \\
& 6.012 & $6.014 \pm 0.141$ & 2.62 \\
& 5.010 & $4.999 \pm 0.141$ & 3.15 \\
& 4.008 & $4.033 \pm 0.339$ & 8.79 \\
Cs-7SB & 3.006 & $2.984 \pm 0.217$ & 7.82 \\
& 1.002 & $1.007 \pm 0.084$ & 9.93 \\
& & & \\
& 1690 & $1682 \pm 92$ & 0.76 \\
BOBCalixC6 & 1521 & $1518 \pm 93$ & 0.79 \\
& 1352 & $1367 \pm 96$ & 0.66 \\
& 845 & $839 \pm 95$ & 1.18 \\
& 126.4 & $125.5 \pm 3.4$ & \\
& 114.9 & $116.1 \pm 4.7$ & 0.17 \\
& 103.4 & $103.3 \pm 4.2$ & 0.65 \\
& 91.9 & $91.9 \pm 3.9$ & 1.00 \\
& 57.5 & $57.3 \pm 4.2$ & 1.04
\end{tabular}

\subsection{Gel Permeation Chromatography method for quantitative and qualitative analysis}

Because of the limitations of the reverse-phase method discussed above, a second, complementary method was developed at ORNL and subsequently applied at SRTC. This method involves a high performance gel permeation chromatography column (GPC). Thus, the separation is based on molecular weight rather than specific interaction with the stationary phase. The column, a Shodex 801, is a non-aqueous size-exclusion material with an exclusion limit of molecular weight approximately 1500 . The mobile phase is chloroform. Flow rate is set at $1 \mathrm{~mL} / \mathrm{min}$. The column temperature is $40^{\circ} \mathrm{C}$. Under these conditions, all analytes elute within 10 minutes.

In addition, the method features the use of two detectors in series. The first detector is an absorbance detector, identical to that used in the reverse phase method described above, while the second is an evaporative light scattering detector (ELD). The ELD operates by evaporating the mobile phase in an optical cell and measuring the light scattering caused by the resulting particles of analyte. Since the light scattering is 
independent of the absorbance, compounds which cannot be detected due to optical transparency do give a response, providing they are sufficiently non-volatile. TOA, for example, is detectable using the ELD, although we found the quantitative aspects of the TOA analysis to be somewhat non-linear.

The method has the following advantages. Due to the use of the GPC column, all potential analytes, both expected and unknown, providing they are soluble in the mobile phase, elute from the column and are detected. This is in contrast to the reverse-phase system, where very polar organics will elute as unretained peaks, and very non-polar organics may not elute at all. Second, all of the peaks are eluted in 10 minutes, providing a significant increase in sample throughput. Third, the method allows for the collection of sample fractions in a volatile solvent. These fractions can be subjected to further instrumental analysis. Finally, by virtue of the elution of materials in order of decreasing molecular weight, the retention time of unknown peaks can be used to assess approximate molecular weight, providing additional qualitative information. The chromatograms shown in Figure 12 illustrate the separation of the calixarene and the modifier using this system and method. The top chromatogram is from the ELD, the bottom from the UV. The signals are recorded simultaneously, although there is a slight time delay due to the solution transport time from the UV detector to the ELD.

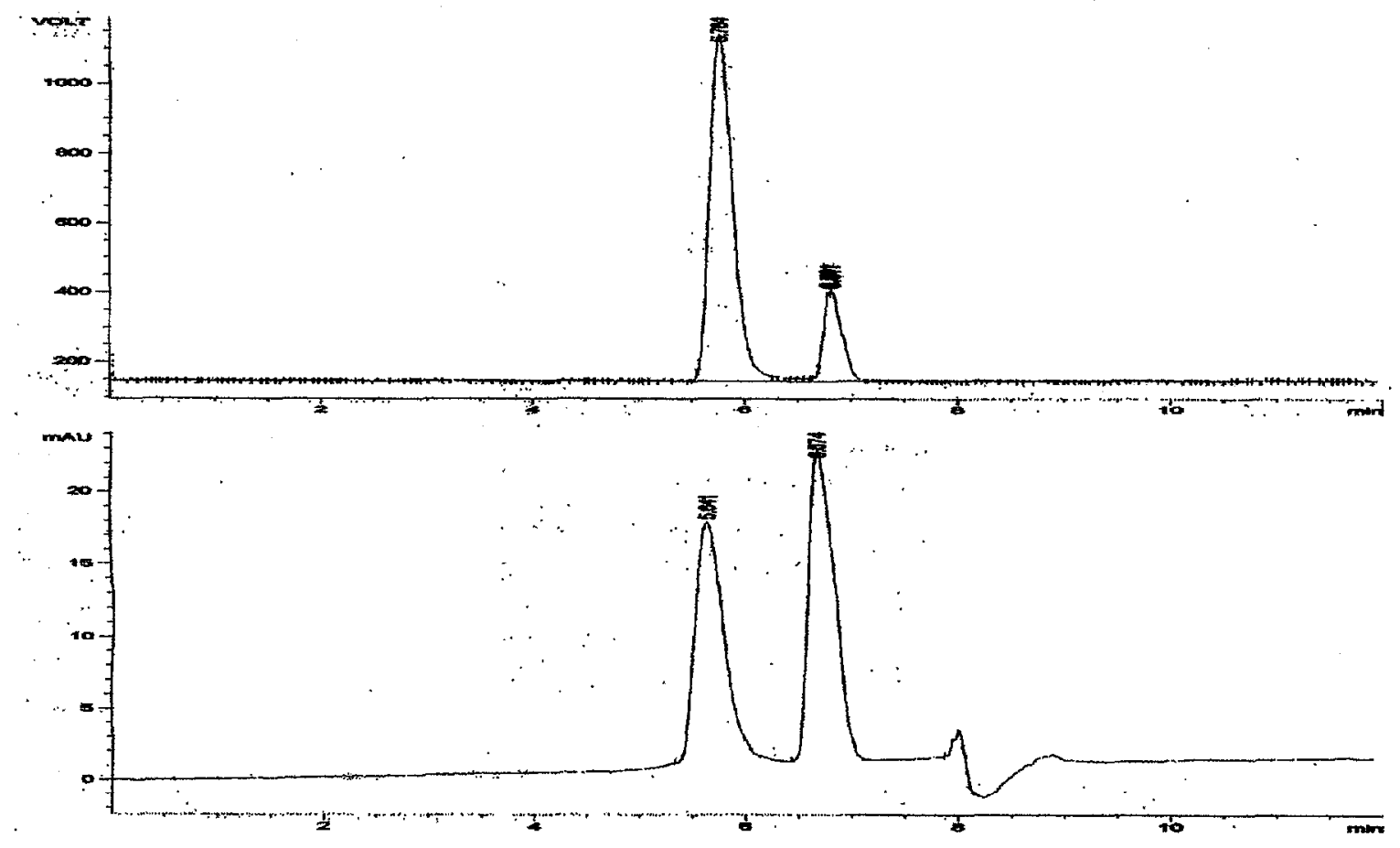

Figure 12. GPC analysis of the solvent system. Top chromatogram is from the ELD. Bottom chromatogram is from the UV absorbance detector. The peak at 5.6 minutes is BOBCalixC6, and the peak at 6.7 minutes is the modifier. 
The two HPLC methods are complementary, in that they can be used in parallel or in series (via collection of the GPC effluent and analysis of the fraction by reverse-phaseHPLC). The GPC method can also provide an estimate of molecular weight for unknown peaks, as shown in Figure 13. This plot illustrates the relationship between molecular weight and elution volume. Because the flow rate is $1 \mathrm{~mL} / \mathrm{min}$., the elution volume is the same as the retention time. In the case of unknown compounds, the plot can be used to approximate molecular weight.

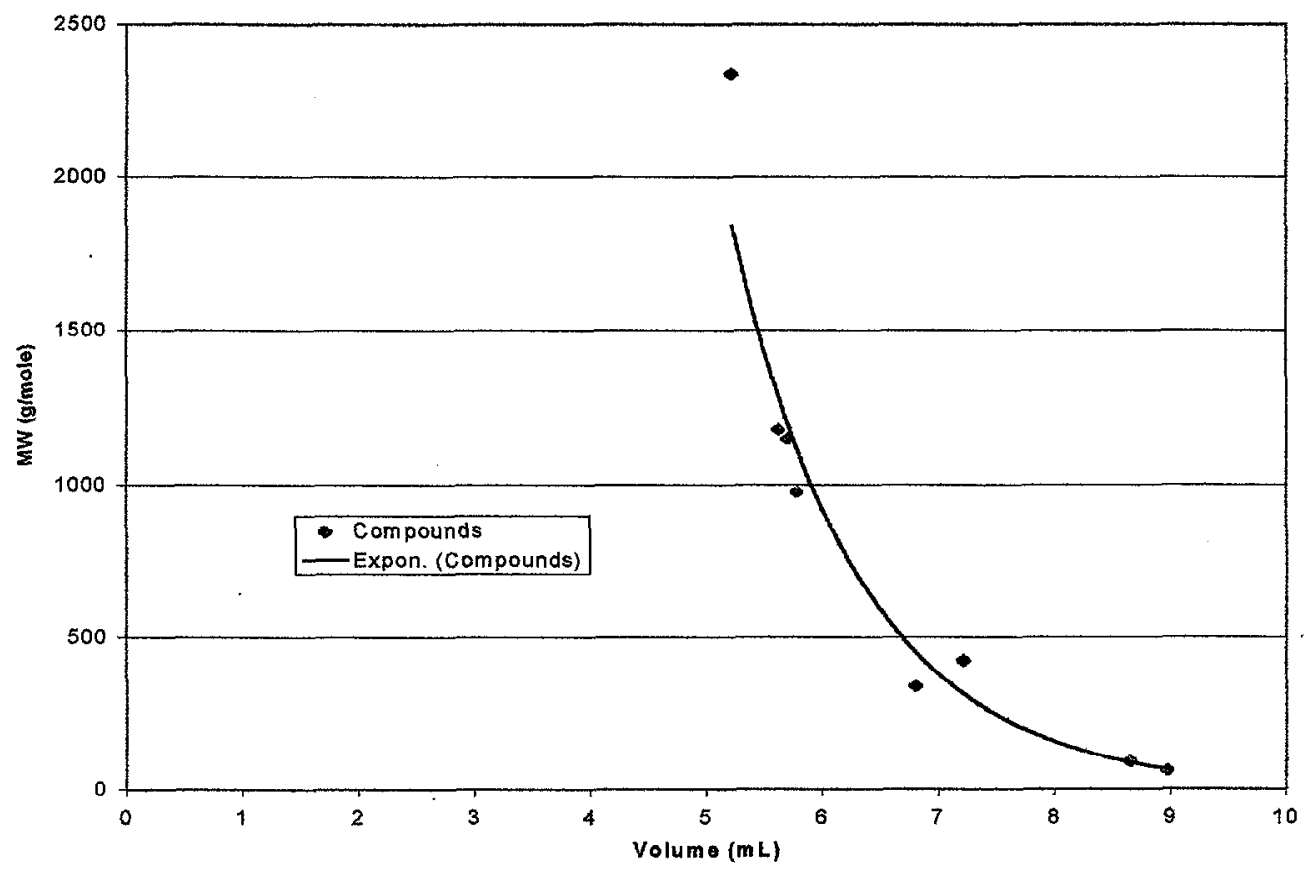

Figure 13. Plot of molecular weight of polystyrene standards versus elution volume The high molecular weight compounds elute earlier.

The quantitative aspects of this method are similar to the reverse-phase method as far as UV detection, although the use of chloroform as the mobile phase restricts the choice of wavelength. The detector response to the analytes was determined to be linear on the diode array detector (observation wavelength of $280 \mathrm{~nm}$ ) over the concentration ranges present in the solvent after a 1:100 dilution. The linear relationships between peak area and concentration of $\mathrm{Cs}-7 \mathrm{SB}$ and $\mathrm{BOBCalixC} 6$ are summarized in Table 2 . The $\%$ RSD for the slopes of Cs-7SB and BOBCalixC6 is about $2 \%$. Calibration curves for the BOBCalixC6, the Cs-7SB, and the 4-sec-butylphenol are shown in Figure 14 through Figure 16. 
Table 2. Linearity of the GPC method for the test compounds

\begin{tabular}{ccccc}
\hline Analyte & $\begin{array}{c}\text { Conc. Range } \\
(\mathrm{mg} / \mathrm{L})\end{array}$ & Slope & Intercept & $\begin{array}{c}\text { Correlation } \\
\text { Coefficient }\end{array}$ \\
\hline Cs-7SB & $850-1700$ & 2.9821 & -12.5 & 1.0 \\
BOBCalixC5 & $60-125$ & 3.5822 & -22.0 & 0.999
\end{tabular}

With respect to the evaporative light scattering detector, the calibration curves were linear over about one order of magnitude. This narrow range is not really a limitation in this application, as the target concentration is known. However, there was still an advantage in terms of precision and linearity for the UV detector at $280 \mathrm{~nm}$.

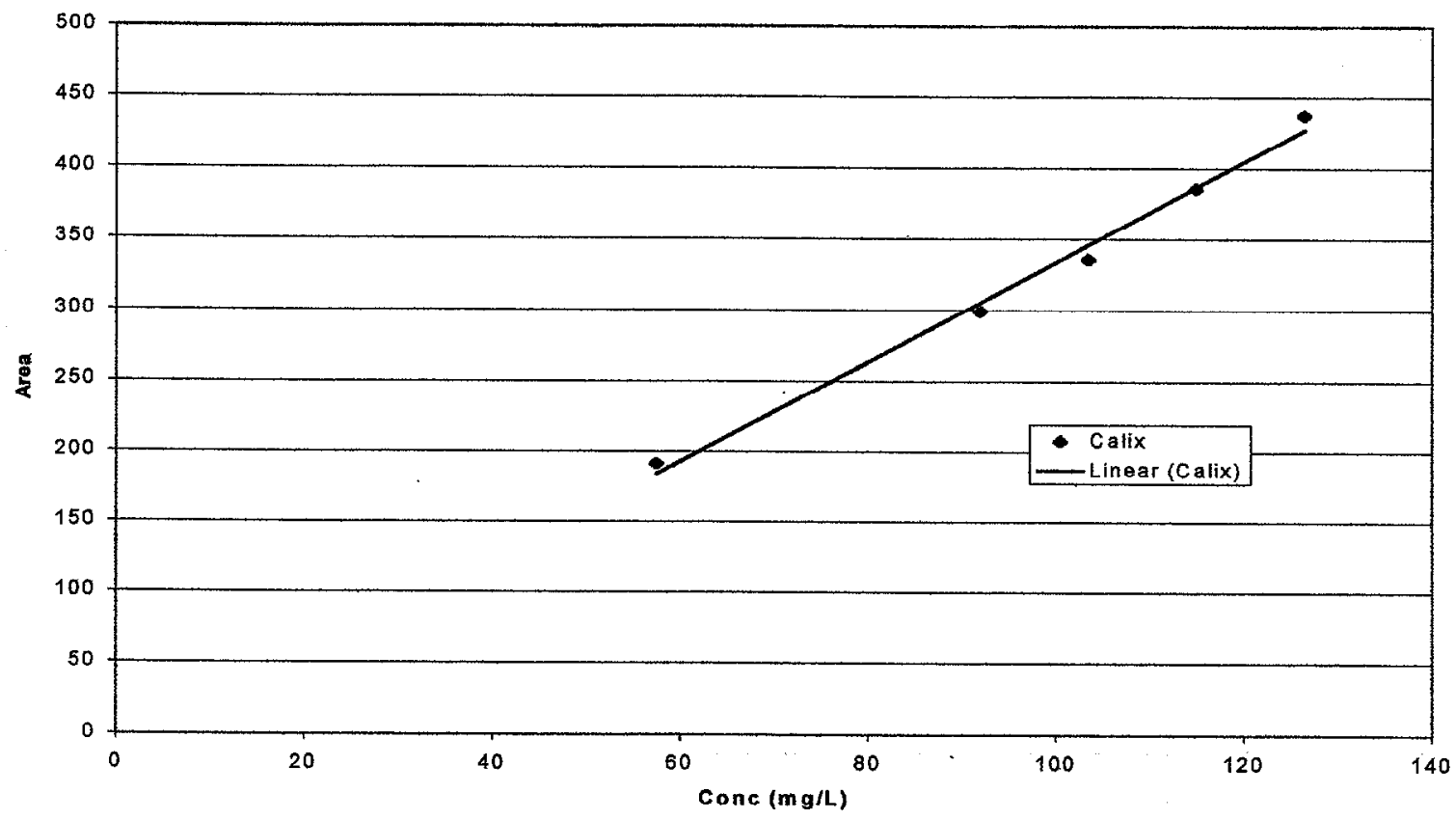

Figure 14. Calibration curve for BOBCalixC6 at $280 \mathrm{~nm}$. 
Document No. CERS/SR/SX/022, Rev. 0

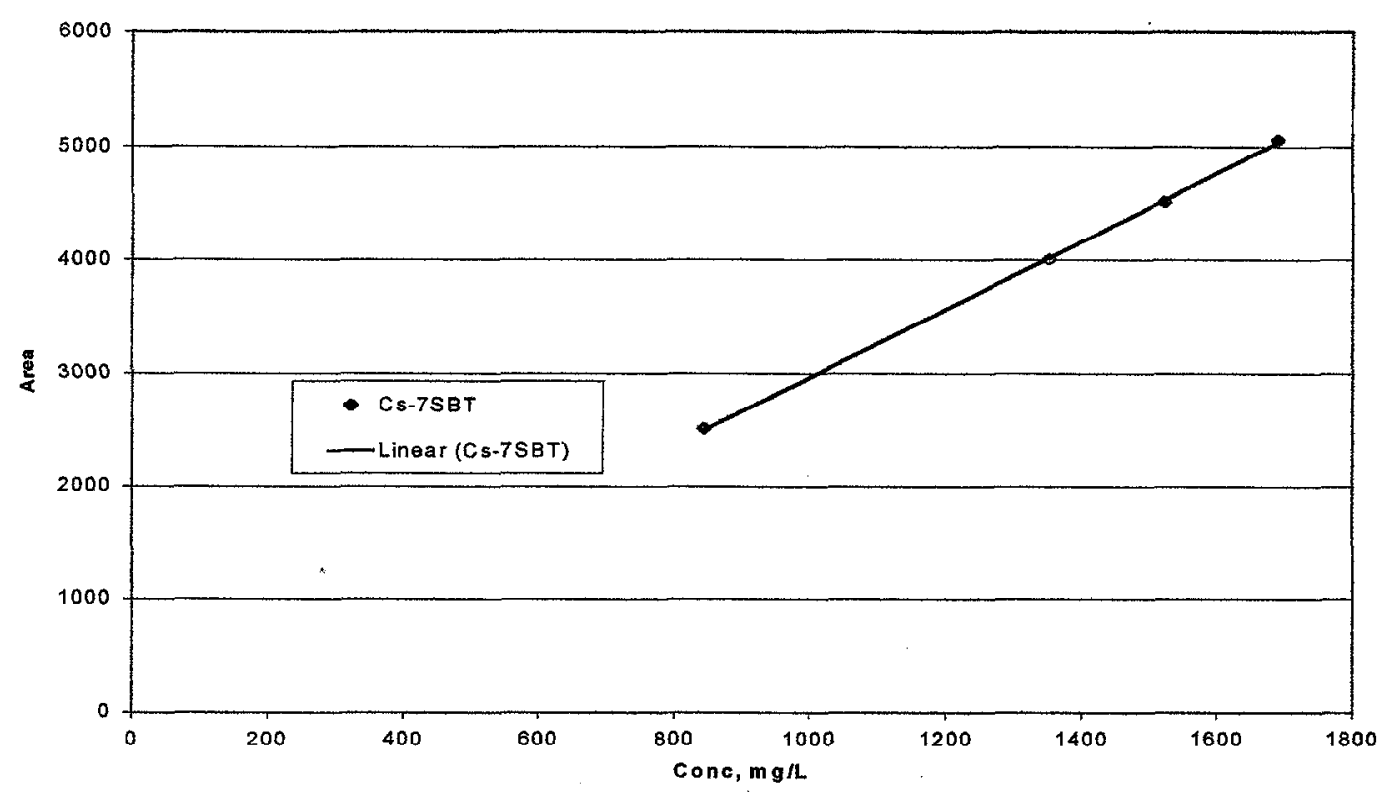

Figure 15. Calibration curve for $\mathrm{Cs}-7 \mathrm{SB}$ at $280 \mathrm{~nm}$.

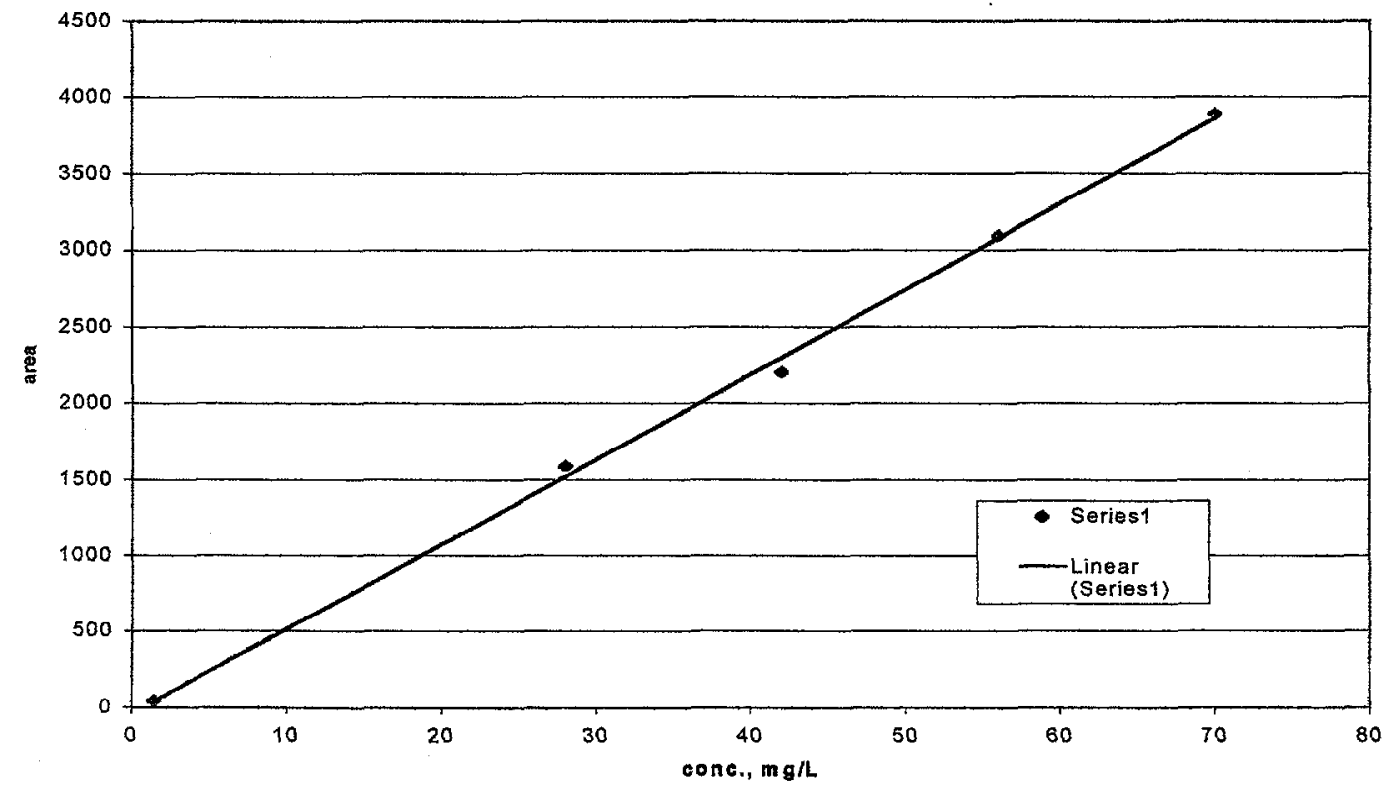

Figure 16. Calibration curve for $4-\mathrm{sec}-$ butylphenol at $280 \mathrm{~nm}$. 


\subsection{Analytical method for tri-n-octylamine (TOA)}

Although the analysis of TOA could be carried out by GPC, it was found that analysis using gas chromatography yielded better results. The advantages include better detection limits (tri-n-octylamine is UV transparent), multiple detector capability, and superior resolution from the modifier, which is in large excess.

The gas chromatography was carried out on a Varian Model 3400 GC equipped with an autosampler and a flame ionization detector (FID). The column was a 30M 3 $0.32 \mathrm{~mm}$ DB-5, 1.0uM film thickness. The temperature profile for the analysis was an initial oven temperature of $70^{\circ} \mathrm{C}$ for 2 minutes, $5^{\circ} \mathrm{C} / \mathrm{min}$. to $150^{\circ} \mathrm{C}, 10^{\circ} \mathrm{C} / \mathrm{min}$. to $250^{\circ} \mathrm{C}$, and a 5 minute hold. Under these conditions, TOA elutes at approximately 25.5 minutes as a symmetrical peak free of interference from the modifier, which elutes at about 22 minutes; a typical chromatogram is shown in Figure 17.

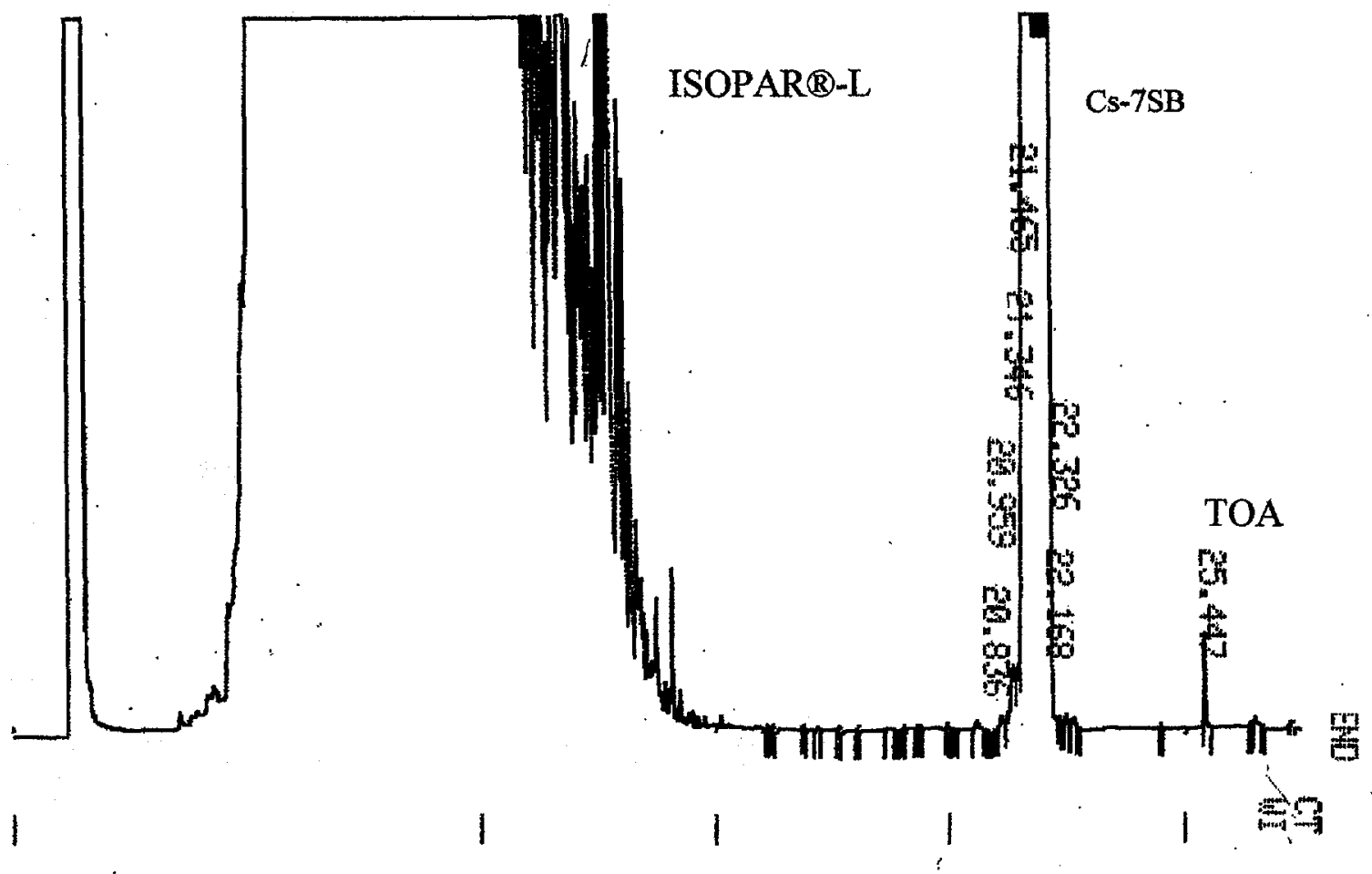

Figure 17. Gas chromatographic analysis of pristine solvent system for tri-noctylamine (retention time of $\mathbf{2 5 . 4 4 7}$ minutes).

Calibration is by external standardization at or near the target concentration. The method is stable and reproducible (replicate injections consistently less than $2 \%$ RSD). 
Standard addition was performed on one of the samples from the internal irradiation experiment, ${ }^{2}$ and the results are shown in Figure 18.

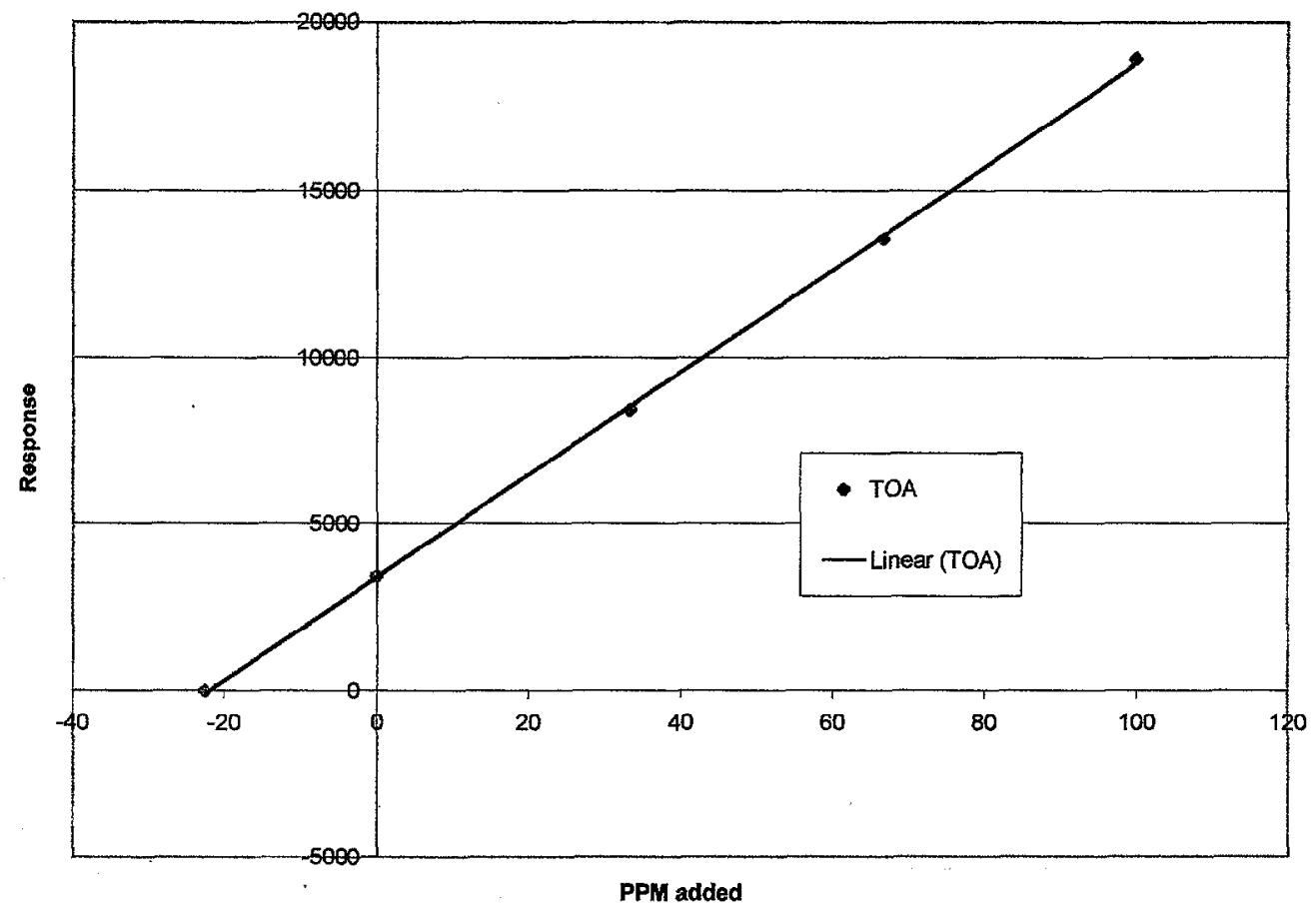

Figure 18. Results of standard addition of tri-n-octylamine to pristine solvent sample.

It should be noted that these conditions are similar to the conditions commonly used for semivolatile organics by GC/MS in EPA methods. ${ }^{3}$ Therefore there is a substantial body of information on the retention time of organic compounds available that can aid the assessment of unknown peaks. Although a portion of the chromatogram is completely obscured by the ISOPARß L diluent, which is the major component in the solvent, there is still the possibility of detecting breakdown products with elution times longer than the ISOPAR $(\mathbb{B}) \mathrm{L}$, as well as the possibility of detecting tributyl phosphate and possibly other materials introduced into the solvent by contact with the simulant or real waste. In addition, the possibility exists to use a mass spectrometer as the detector rather than an FID. A method based on GC/MS was developed at ORNL and also at SRTC. The method is similar in performance to the FID method, although for the long term, GC/MS may be preferable for reasons noted below with respect to solvent breakdown products and the retention of components from the waste stream. 


\subsection{Extension of the analytical methods to possible breakdown products}

As mentioned earlier, it was considered necessary to develop methods which would allow at least the possibility of detecting breakdown products of the components of the solvent system. Through the course of this work, two major breakdown products were identified: 4-sec-butylphenol and dioctylamine. The 4-sec-butylphenol is a result of breakdown of the modifier and the dioctylamine results from breakdown of the tri-noctylamine . Furthermore, with respect to analysis of the solvent system under operating conditions, it would be preferable to use methods which would offer the possibility of providing qualitative information on minor components from the real waste, particularly those with the potential for affecting the efficiency of the CSSX process. These factors led to an investigation of the possibility of using GC/MS rather than GC/FID or reversephase HPLC for the analysis of 4-sec-butylphenol, di-n-octylamine, and tri-n-octylamine. The details of the analysis of tri-n-octylamine were worked out largely at SRTC, due to the fact that a GC/MS was available. This method uses single ion monitoring to quantitatively measure the tri-n-octylamine and 4-sec-butylphenol. Analytical separations were carried out on a Hewlett Packard 6890 gas chromatograph, equipped with a $30 \mathrm{~m}$ DB-5 column, with $0.25 \mathrm{~mm}$ diameter and 0.25 um film thickness. Quantitation was performed using a Hewlett Packard 5973 mass selective detector. Selected ion monitoring, ion 254 for TOA and ion 121 for 4-sec-butylphenol, was used to obtain the chromatogram shown in Figure 19. This method also proved useful for quantitative analysis. Relative standard deviations for replicate sample analysis were typically $<3 \%$.

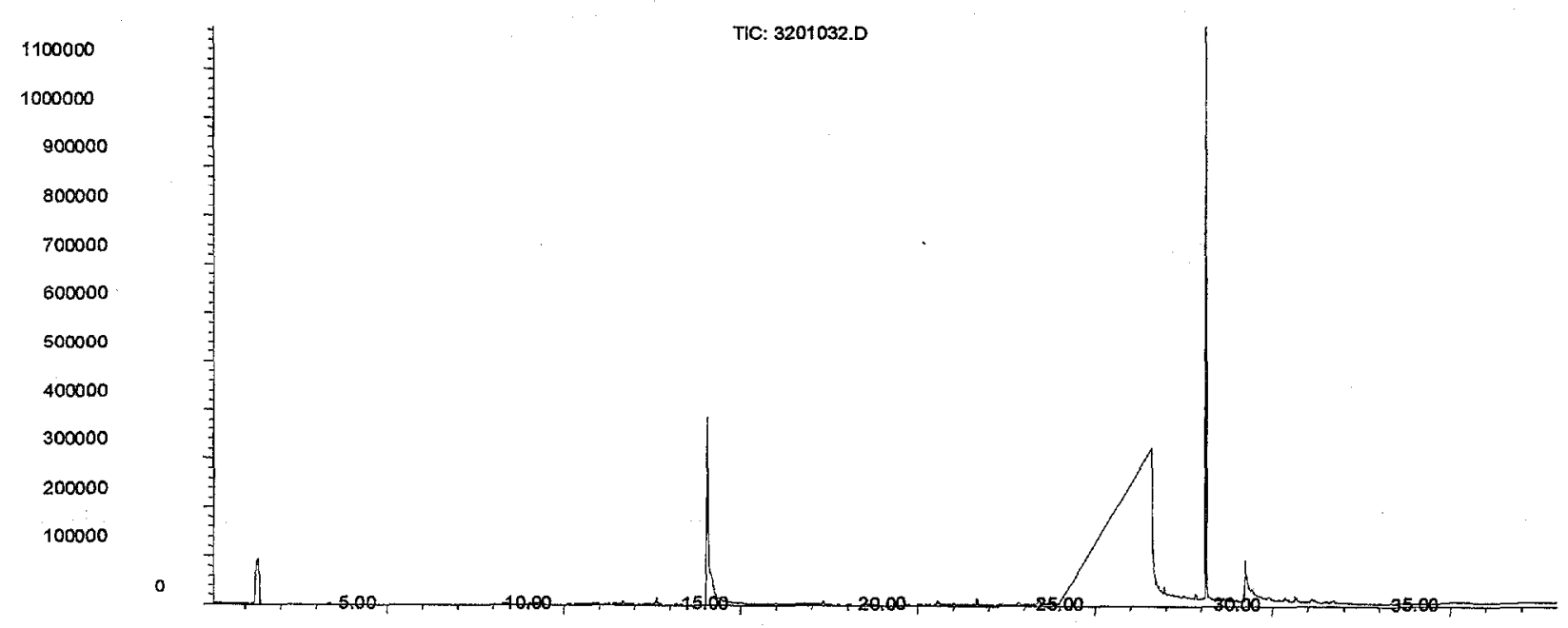

Figure 19. Mass chromatogram of 4-sec-butylphenol (15 minutes), and tri-noctylamine ( 28 minutes). 
One additional approach was investigated for the analysis of di-n-octylamine and tri-n-octylamine. During the thermal stability experiment (3) pristine solvent samples were stored at elevated temperatures over the various aqueous phases. It was noticed that there was degradation of tri-n-octylamine at elevated temperature in solvent over the scrub solution ( $0.05 \mathrm{M}$ nitrate). Initially, di-n-octylamine was formed. However, as time progressed, the di-n-octylamine also appeared to be degrading. A logical assumption would be that the di-n-octylamine was degrading to octylamine. However, octylamine elutes in the portion of the chromatogram obscured by the ISOPAR® L. Therefore, a gas chromatographic method similar to the above method in terms of GC conditions but employing an alkali flame ionization detector (NPD) was used to visualize the nitrogencontaining species in the sample. A chromatogram of standard solutions of the three major expected components is shown in Figure 20.

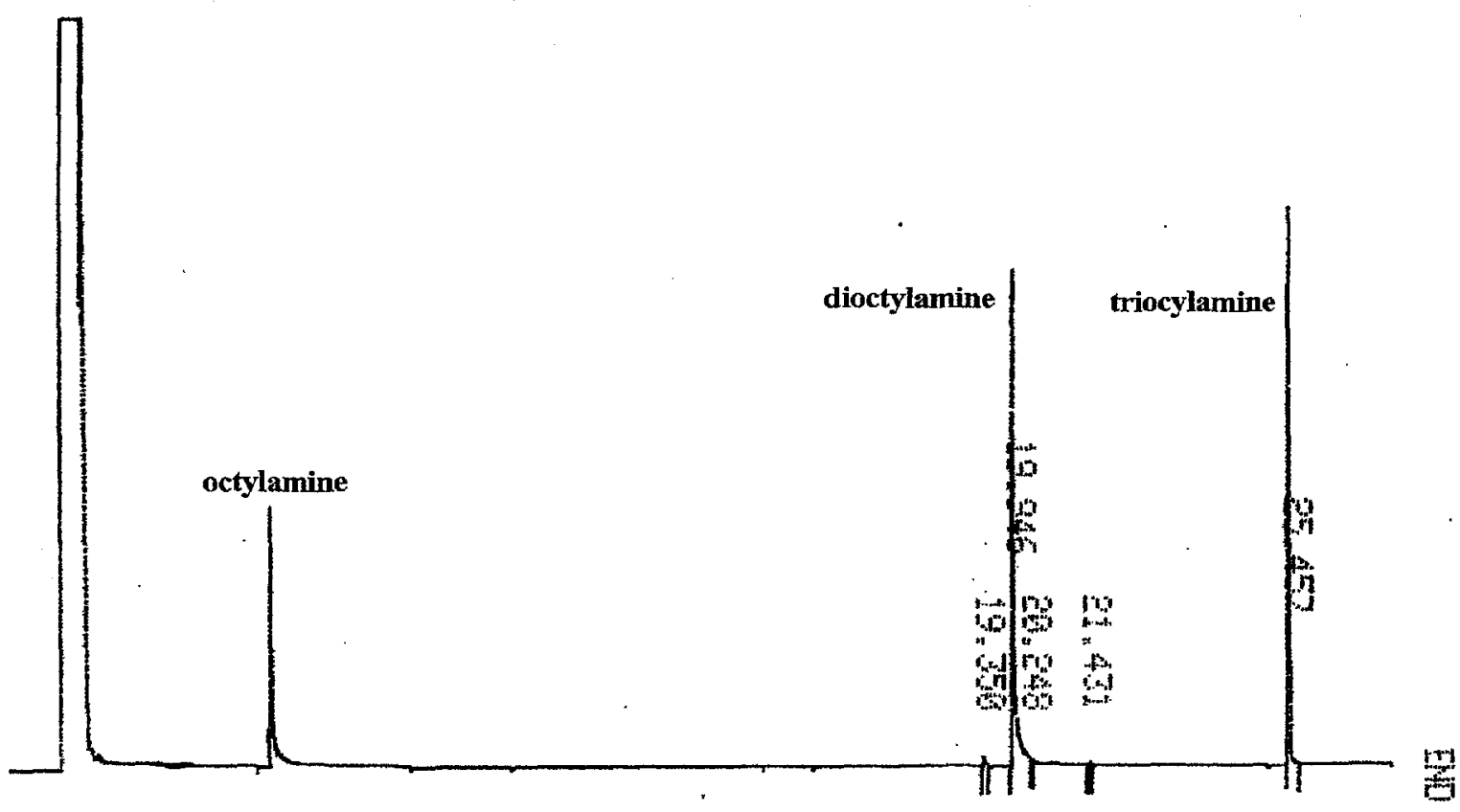

Figure 20. Chromatogram of the expected thermal breakdown products of tri-noctylamine.

Analysis of the solvent system prior to thermal treatment using the NPD is shown in Figure 21. Note the minimal interference from the ISOPARß $\mathrm{L}$, which elutes in the range of 10-16 minutes. The asymmetric peak at 26 minutes is due to the extrmely high concentration of Cs-7SB. Nevertheless, if there were nitrogen-containing species coeluting with the Cs-7SB, it is likely that they would be detected here. The retention time of the TOA is slightly longer than in earlier chromatograms due to the fact that the column film thickness is greater ( $1.0 \mathrm{uM}$ vs. $0.25 \mathrm{uM})$. 


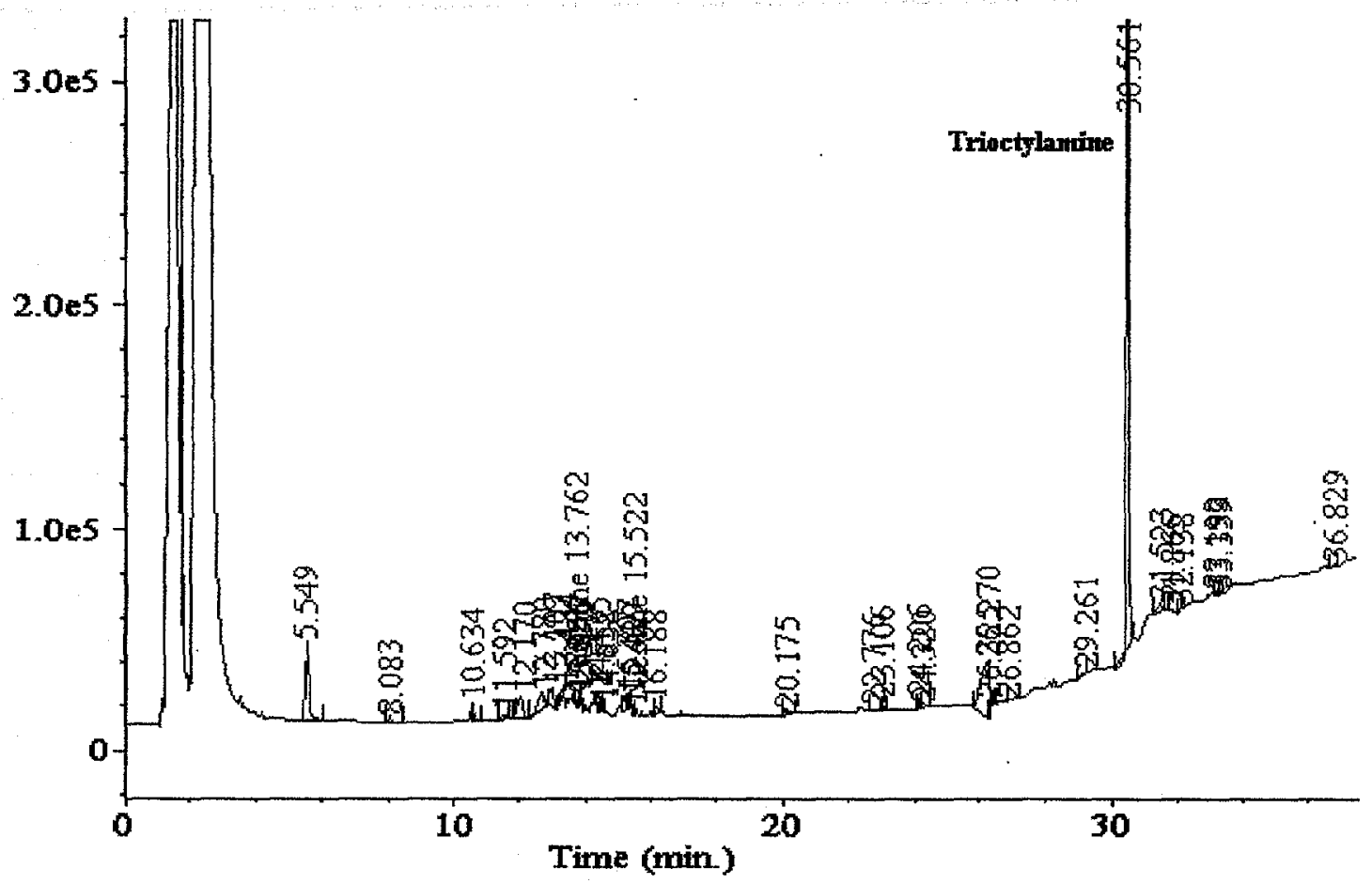

Figure 21. Analysis of the solvent system prior to thermal treatment using a nitrogen-selective detector.

An chromatogram of a degraded sample from the thermal stability experiment is shown in Figure 22. No octylamine was seen, but there are several small peaks eluting between the dioctylamine and the tri-n-octylamine. An attempt was made to identify these components via GC/MS, but their concentration was too low to acquire a reasonable mass spectrum. However, from this analysis it can be concluded that no major nitrogen containing compounds will be present in the solvent as a result of degradation of the tri-n-octylamine. Thus, the use of similar GC conditions combined with multiple detectors offers the possibility of enhanced characterization of the solvent system. This capability may prove extremely useful during plant operation with real waste components. 


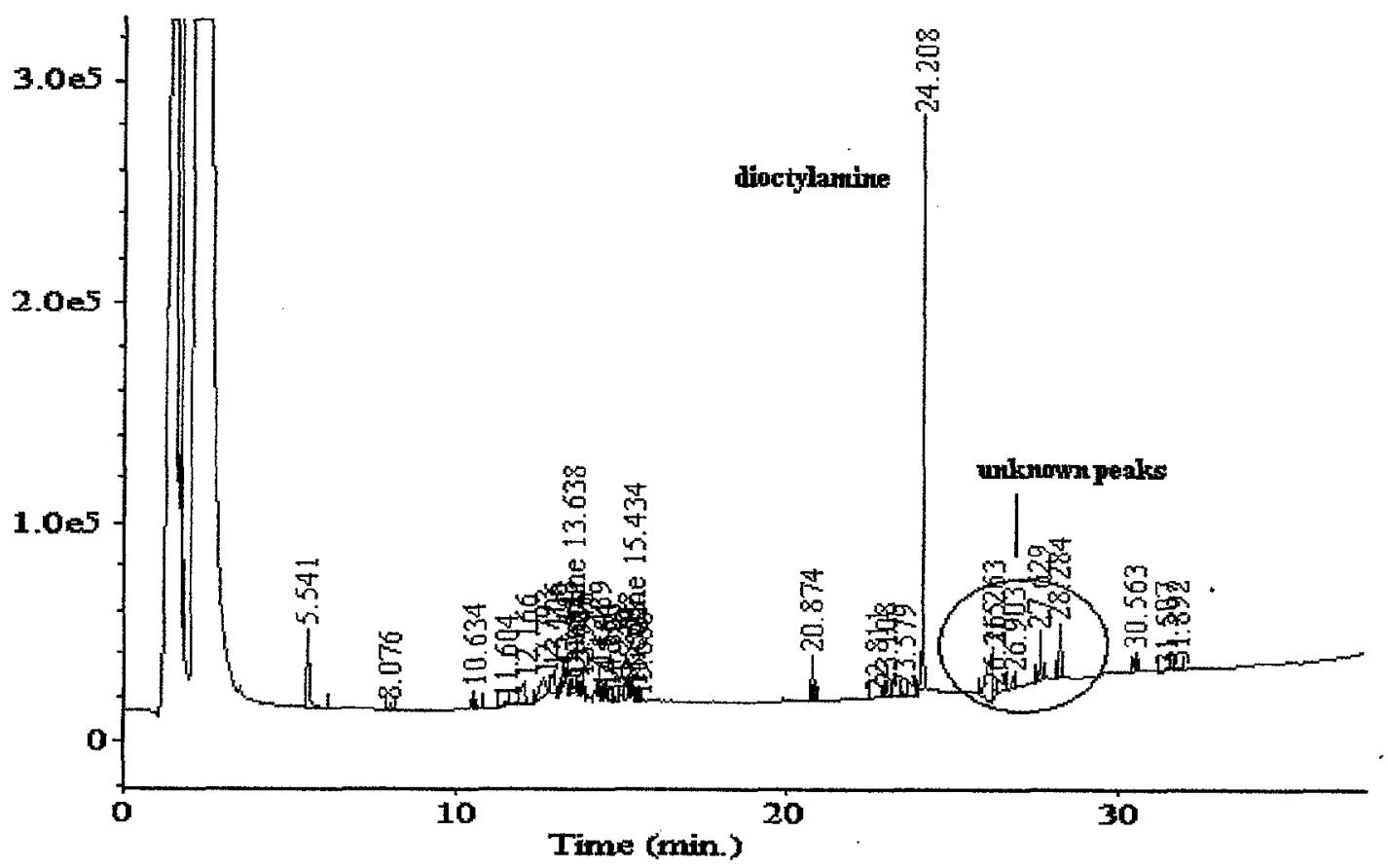

Figure 22. Analysis of thermally degraded sample.

\section{Recommendations for process analysis.}

An additional objective of this work was to make recommendations as to the type and frequency of analyses to be carried out in the plant setting. Some of these issues are resolved by examination of the behavior of the solvent system when subjected to extreme conditions. After external irradiation, internal irradiation, multiple process cycling, and thermal treatment well beyond that expected in process operation, it is clear that the calixarene and modifier are quite stable. ${ }^{4}$ Therefore, there appears to be no real need for continuous monitoring of these components during plant operation. This would seem to offer the opportunity for operational cost savings. However, an off-line analytical capability still needs to be established. This capability might consist of analysis by either HPLC method. Since the number of samples to be analyzed will likely be low, and turnaround time requirements not terribly important, a case could be made for the use of the reverse phase method, based on the fact that the method does not produce a mixed waste. However, for the purpose of examining samples in the case of process upset, the qualitative advantages of the dual-detector GPC method will be useful. Therefore, the recommendation is for the use of reverse-phase HPLC for routine process analysis and 
quality assurance of the solvent system, and for the use of the dual-detector GPC system for unusual circumstances.

Studies ${ }^{4}$ indicated that there was a lower degree of stability in the tri-n-octylamine concentration during treatment at extremes, and that furthermore there is some matrix specificity in the response (hence the addition of triethylamine during dilution). Thus, there may be a reason to conduct more frequent analysis for this solvent component. In addition, by using GC/MS, the tri-n-octylamine can be analyzed coincidentally with 4sec-butylphenol. The acquisition and use of isotopically labeled tri-n-octylamine and 4sec-butyl phenol would allow precise and accurate measurement of these two compounds regardless of matrix, and regular analysis of 4-sec-butylphenol would provide an early indication of modifier breakdown. Furthermore, GC/MS would provide qualitative information on any additional components entering the system from the real waste (e.g., tributylphosphate). Thus, it is recommended that regular analysis of tri-n-octylamine and 4-sec-butylphenol be conducted by GC/MS, using extracted ion current profiling rather than SIM (in order to preserve the qualitative information), and using stable isotopes for quantitative analysis.

Perhaps the most important analysis from a process point of view is the composition of the incoming waste. This will be true regardless of the nature of the separation process. However, the nature of the solvent extraction process is that a limited number of possible waste constituents have the potential for causing major upsets in process operation. Plant operation experience will define which parameters will need to be monitored, and at what frequency. As experience is gained on the variability of the waste feed, an adequate process control plan will be developed.

\section{Summary}

In summary, two HPLC methods and one GC method have been developed and implemented for the analysis of samples related to this project. In addition, a solid phase extraction system has been applied to the separation of organic compounds from aqueous materials which come in contact with the solvent. The combination of these methods allows both quantitative analysis of the major components of the solvent, and visualization of any minor components, including breakdown products.

\section{References}

1. T. L. White, R. a. Peterson, F. F. Fondeur, and C. L. Crawford, "Determination of Calix[4]arene-bis( $t$-octylbenzocrown-6), 1-(1,1,2,2-tetrafluoroethoxy)-3-[4( $t$ octyl)phenoxy]-2-propanol and 4-(tertoctyl)phenol in ISOPAR® L Solvent by High Performance Liquid Chromatography (HPLC)", Personal Communication, April, 2000 SRTC method. 
2. R. D. Spence, L. H. Delmau, L. N. Klatt, F. V. Sloop, Jr., P. V. Bonnesen, and B. A. Moyer, "Batch-Equilibrium Hot-Cell Tests of Caustic-Side Solvent Extraction (CSSX) with SRS Simulant Waste and Internal ${ }^{137}$ Cs Irradiation," CERS/SR/SX/021, Rev. 0, April 2001.

3. Test Methods for Evaluating Solid Waste, EPA 600-SW-846, November, 1986.

4. Bruce A. Moyer, Spiro D. Alexandratos, Peter V. Bonnesen, Gilbert M. Brown, John E. Caton, Jr., Lætitia H. Delmau, Caroline R. Duchemin, Tamara J. Haverlock, Tatiana G. Levitskaia, Michael P. Maskarinec, and Frederick V. Sloop, Jr., "CausticSide Solvent Extraction Chemical and Physical Properties. Progress in FY 2000 and FY 2001," CERS/SR/SX/019, April 2001.

\section{Acknowledgements}

The authors wish to express their appreciation to Todd Skeen, Sara Harmon, Paul Wolfe, Steve Crump, and Bruce Tomkins for their technical assistance, and to Roger Jenkins for assistance in the review of this report. 
9. Appendix 1. Calibration data for reverse-phase HPLC method.

All concentrations in $\mathrm{mg} / \mathrm{L}$.

\section{DETECTION LIMITS ACCORDING TO HUBAUX AND VOS}

*_*TITLE: BOBCalixC6 calibration on RP HPLC @, 226 nm INPUTS 1. CALIBRATION POINTS STARTING AT X11 AND Y11

$\begin{array}{llll}\text { NEEDED: } 2 \text {. } \mathrm{t} \text { FOR UPPER CURVE } & 1.8600 & 95.0000 & \% \text { CONFID } \\ \text { 3. } \mathrm{t} \text { FOR LOWER } & 1.8600 & 95.0000 & \% \text { CONFID } \\ \text { CURVE } & & & \end{array}$

$\begin{array}{rc}\text { DET LIM } & \mathbf{0 . 6 3 4} \\ \text { QUANT LM } & 1.266 \\ \text { Intercept, a } & \mathbf{1 2 . 0 7 4} \\ \text { St Dev a } & \mathbf{1 6 . 1 8 7} \\ \text { Slope, b } & \mathbf{5 1 . 7 2 5} \\ & \\ \text { St Dev b } & \mathbf{0 . 1 3 5} \\ \text { R Squared } & \mathbf{0 . 9 9 9 9 5}\end{array}$

\begin{tabular}{|c|c|c|}
\hline CROSSES? YES & Area at Quant Limit & 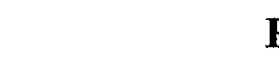 \\
\hline CALIBRATION POINTS & ERROR LIMIT CURVES & INCREMENTS \\
\hline
\end{tabular}

$\begin{array}{cccccccc}\text { CONC-X } & \text { RESP-Y } & \text { CALC Y } & \text { UPPER Y } & \text { LOWER Y } & \text { UP INC } & \text { LOW INC } & \text { conc/resp } \\ 1.15 & 70.5 & 71.6 & 104 & 39 & 33 & 33 & 0.01631 \\ 2.88 & 166.0 & 161.0 & 194 & 128 & 33 & 33 & 0.01735 \\ 5.75 & 314.0 & 309.5 & 342 & 277 & 32 & 32 & 0.01831 \\ 11.5 & 600.0 & 606.9 & 639 & 575 & 32 & 32 & 0.01917 \\ 23 & 1191.0 & 1201.7 & 1234 & 1170 & 32 & 32 & 0.01931 \\ 46 & 2379.0 & 2391 & 2423 & 2360 & 32 & 32 & 0.01934 \\ 69 & 3617.0 & 3581 & 3614 & 3548 & 33 & 33 & 0.01908 \\ 92 & 4770.0 & 4771 & 4806 & 4736 & 35 & 35 & 0.01929 \\ 115 & 5947.0 & 5960 & 5998 & 5923 & 38 & 38 & 0.01934\end{array}$




\section{DETECTION LIMITS ACCORDING TO HUBAUX AND VOS}

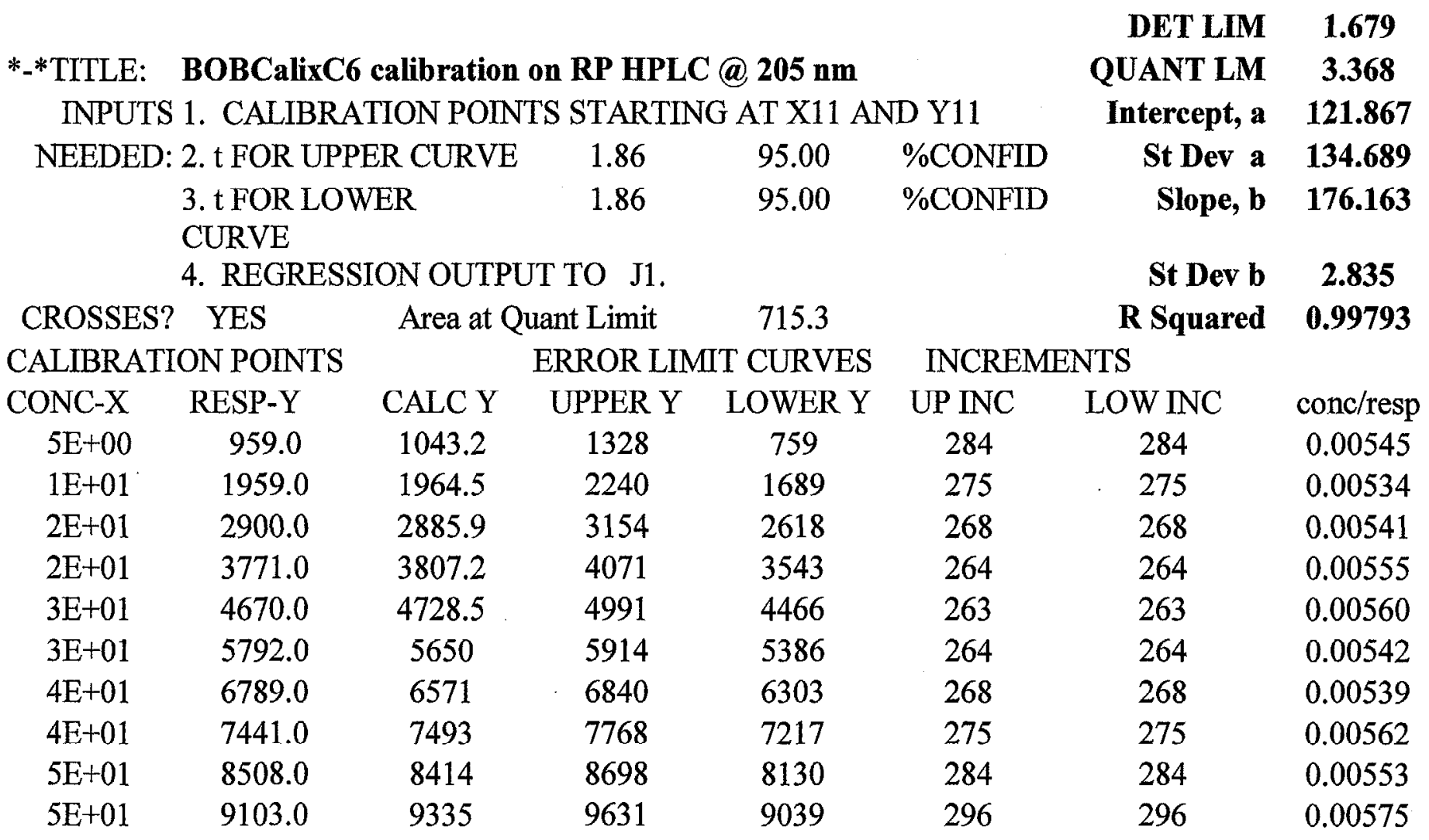




\section{DETECTION LIMITS ACCORDING TO HUBAUX AND VOS}

\begin{tabular}{|c|c|c|c|c|c|c|c|}
\hline $\begin{array}{l}\text { *_*TITLE: } \\
\text { INPUTS }\end{array}$ & $\begin{array}{l}\text { BOBCalix( } \\
\text { 1. CALIBR }\end{array}$ & $\begin{array}{l}\text { alibration } \\
\text { ION POIN }\end{array}$ & START & $\begin{array}{l}\mathbf{a} \mathbf{2 5 4} \mathbf{n m} \\
\mathrm{AT} X 11 \mathrm{Al}\end{array}$ & D Y11 & $\begin{array}{r}\text { QUANT LM } \\
\text { Intercept, a }\end{array}$ & $\begin{array}{c}1.673 \\
12.000\end{array}$ \\
\hline NEEDED: & 2. $t$ FOR UP & ER CURVE & 1.86 & 95.00 & $\%$ CONFID & St Dev a & 20.214 \\
\hline & $\begin{array}{l}\text { 3. } t \text { FOR LO } \\
\text { CURVE }\end{array}$ & ER & 1.86 & 95.00 & $\%$ CONFID & Slope, b & 53.071 \\
\hline & 4. REGRES & ION OUTP & T TO J1. & & & St Dev b & 0.426 \\
\hline CROSSES? & YES & Area at $\mathrm{C}$ & ant Limit & 100.8 & & R Squared & 0.99949 \\
\hline CALIBRATI & ON POINTS & & ERROR LII & IT CURVES & INCREM & NTS & \\
\hline CONC-X & RESP-Y & CALC Y & UPPER Y & LOWER Y & UP INC & LOW INC & conc/resp \\
\hline $5 \mathrm{E}+00$ & 284.0 & 289.6 & 332 & 247 & 43 & 43 & 0.01842 \\
\hline $1 \mathrm{E}+01$ & 584.0 & 567.1 & 608 & 526 & 41 & 41 & 0.01791 \\
\hline $2 E+01$ & 835.0 & 844.7 & 885 & 804 & 40 & 40 & 0.01879 \\
\hline $2 \mathrm{E}+01$ & 1124.0 & 1122.3 & 1162 & 1083 & 40 & 40 & 0.01861 \\
\hline $3 \mathrm{E}+01$ & 1377.0 & 1399.8 & 1439 & 1360 & 39 & 39 & .0 .01899 \\
\hline $3 \mathrm{E}+01$ & 1677.0 & 1677 & 1717 & 1638 & 40 & 40 & 0.01871 \\
\hline $4 \mathrm{E}+01$ & 1999.0 & 1955 & 1995 & 1915 & 40 & 40 & 0.01831 \\
\hline $4 \mathrm{E}+01$ & 2214.0 & 2233 & 2274 & 2191 & 41 & 41 & 0.01890 \\
\hline $5 \mathrm{E}+01$ & 2503.0 & 2510 & 2553 & 2467 & 43 & 43 & 0.01881 \\
\hline $5 \mathrm{E}+01$ & 2789.0 & 2788 & 2832 & 2743 & 44 & 44 & 0.01875 \\
\hline
\end{tabular}




\section{DETECTION LIMITS ACCORDING TO HUBAUX AND VOS}

*_*TITLE: Modifier Cs-7SB calibration on RP HPLC @ 205 nm

INPUTS 1. CALIBRATION POINTS STARTING AT X11 AND Y11

$\begin{array}{llll}\text { NEEDED: 2. t FOR UPPER CURVE . } & 1.86 & 95.00 & \% \text { CONFID } \\ \text { 3. t FOR LOWER } & 1.86 & 95.00 & \% \text { CONFID } \\ \text { CURVE } & & & \end{array}$

$\begin{array}{rc}\text { DET LIM } & \mathbf{3 . 1 4 5} \\ \text { QUANT LM } & \mathbf{6 . 5 0 5} \\ \text { Intercept, a } & \mathbf{1 0 8 . 8 6 7} \\ \text { St Dev a } & \mathbf{4 4 . 8 9 7} \\ \text { Slope, b } & \mathbf{3 1 . 3 5 4} \\ & \\ \text { St Dev b } & \mathbf{0 . 2 5 7} \\ \text { R Squared } & \mathbf{0 . 9 9 9 4 6}\end{array}$

CROSSES? YES

N OUTPUT TO J1

312.8

R Squared

.99946

CALIBRATION POINTS

ERROR LIMIT CURVES INCREMENTS

$\begin{array}{rrrccccc}\text { CONC-X } & \text { RESP-Y } & \text { CALC Y } & \text { UPPER Y } & \text { LOWER Y } & \text { UP INC } & \text { LOW INC } & \text { conc/resp } \\ 2 \mathrm{E}+01 & 647.0 & 710.9 & 806 & 616 & 95 & 95 & 0.02968 \\ 4 \mathrm{E}+01 & 1313.0 & 1312.8 & 1405 & 1221 & 92 & 92 & 0.02925 \\ 6 \mathrm{E}+01 & 1943.0 & 1914.8 & 2004 & 1825 & 89 & 89 & 0.02964 \\ 8 \mathrm{E}+01 & 2570.0 & 2516.8 & 2605 & 2429 & 88 & 88 & 0.02988 \\ 1 \mathrm{E}+02 & 3119.0 & 3118.8 & 3206 & 3031 & 88 & 88 & 0.03078 \\ 1 \mathrm{E}+02 & 3738.0 & 3721 & 3809 & 3633 & 88 & 88 & 0.03082 \\ 1 \mathrm{E}+02 & 4372.0 & 4323 & 4412 & 4233 & 89 & 89 & 0.03074 \\ 2 \mathrm{E}+02 & 4850.0 & 4925 & 5016 & 4833 & 92 & 92 & 0.03167 \\ 2 \mathrm{E}+02 & 5516.0 & 5527 & 5622 & 5432 & 95 & 95 & 0.03133 \\ 2 \mathrm{E}+02 & 6130.0 & 6129 & 6227 & 6030 & 99 & 99 & 0.03132\end{array}$




\begin{tabular}{|c|c|c|c|c|c|c|c|}
\hline \multicolumn{8}{|c|}{ DETECTION LIMITS ACCORDING TO HUBAUX AND VOS } \\
\hline & \multirow{2}{*}{\multicolumn{5}{|c|}{ Modifier Cs-7SB calibration on RP HPLC $₫ 226 \mathrm{~nm}$}} & DET LIM & 4.300 \\
\hline \multirow{3}{*}{$\begin{array}{c}\text { *_*TITLE: } \\
\text { INPUT: } \\
\text { NEEDED }\end{array}$} & & & & & & QUANT LM & 8.639 \\
\hline & \multicolumn{5}{|c|}{ 1. CÁLIBRATION POINTS STARTING AT X11 AND Y11 } & Intercept, a & 64.467 \\
\hline & \multirow{2}{*}{\multicolumn{2}{|c|}{$\begin{array}{l}\text { 2. t FOR UPPER CURVE } \\
\text { 3. t FOR LOWER }\end{array}$}} & 1.86 & 95.00 & $\%$ CONFID & St Dev a & 81.141 \\
\hline & & & 1.86 & 95.00 & $\%$ CONFID & Slope, $\mathbf{b}$ & 41.439 \\
\hline & \multicolumn{5}{|l|}{ CURVE } & & \\
\hline & \multicolumn{5}{|c|}{ 4. REGRESSION OUTPUT TO $\mathrm{J} 1$. } & St Dev b & 0.465 \\
\hline CROSSES? & YES & Area at $\mathrm{Ql}$ & ant Limit & 422.5 & & R Squared & 0.99899 \\
\hline \multicolumn{5}{|c|}{ CALIBRATION POINTS } & \multicolumn{2}{|c|}{ INCREMENTS } & \\
\hline CONC-X & RESP-Y & CALC Y & UPPER Y & LOWER Y & UP INC & LOW INC & conc/resp \\
\hline $2 \mathrm{E}+01$ & 849.0 & 860.1 & 1031 & 689 & 171 & 171 & 0.02261 \\
\hline $4 \mathrm{E}+01$ & 1652.0 & 1655.7 & 1821 & 1490 & 166 & 166 & 0.02324 \\
\hline $6 \mathrm{E}+01$ & 2481.0 & 2451.3 & 2613 & 2290 & 162 & 162 & 0.02322 \\
\hline $8 \mathrm{E}+01$ & 3288.0 & 3247.0 & 3406 & 3088 & 159 & 159 & 0.02336 \\
\hline $1 \mathrm{E}+02$ & 3956.0 & 4042.6 & 4201 & 3884 & 158 & 158 & 0.02427 \\
\hline $1 \mathrm{E}+02$ & 4869.0 & 4838 & 4997 & 4679 & 159 & 159 & 0.02366 \\
\hline $1 \mathrm{E}+02$ & 5738.0 & 5634 & 5795 & 5472 & 162 & 162 & 0.02342 \\
\hline $2 \mathrm{E}+02$ & 6264.0 & 6429 & 6595 & 6264 & 166 & 166 & 0.02452 \\
\hline $2 \mathrm{E}+02$ & 7229.0 & 7225 & 7396 & 7054 & 171 & 171 & 0.02390 \\
\hline $2 \mathrm{E}+02$ & 8078.0 & 8021 & 8199 & 7843 & 178 & 178 & 0.02377 \\
\hline
\end{tabular}


DETECTION LIMITS ACCORDING TO HUBAUX AND VOS

\begin{tabular}{|c|c|c|c|c|c|c|c|}
\hline $\begin{array}{l}\text { *_*TITLE: } \\
\text { INPUTs }\end{array}$ & & ID Y11 & $\begin{array}{r}\text { DET LIM } \\
\text { QUANT LM } \\
\text { Intercept, a }\end{array}$ & $\begin{array}{c}6.493 \\
12.772 \\
0.333\end{array}$ \\
\hline NEEDED: & 2. $\mathrm{t} F \mathrm{RO}$ UP & R CURVE & 1.86 & 95.00 & $\%$ CONFID & St Dev a & $\mathbf{3 . 9 8 3}$ \\
\hline & $\begin{array}{l}\text { 3. } t \text { FOR LO } \\
\text { CURVE }\end{array}$ & & 1.86 & 95.00 & $\%$ CONFID & Slope, $\mathbf{b}$ & 1.347 \\
\hline & 4. REGRES & ON OUTP & T TO J1. & & & St Dev b & 0.023 \\
\hline CROSSES? & YES & Area at $Q$ & ant Limit & 17.5 & & R Squared & 0.99771 \\
\hline CALIBRATI & ON POINTS & & ERROR LII & [T CURVES & INCREMI & NTS & \\
\hline CONC-X & RESP-Y & CALC Y & UPPER Y & LOWER Y & UP INC & LOW INC & conc/resp \\
\hline $2 \mathrm{E}+01$ & 27.0 & 26.2 & 35 & 18 & 8 & 8 & 0.71111 \\
\hline $4 \mathrm{E}+01$ & 51.0 & 52.1 & 60 & 44 & 8 & 8 & 0.75294 \\
\hline $6 \mathrm{E}+01$ & 80.0 & 77.9 & 86 & 70 & 8 & 8 & 0.72000 \\
\hline $8 \mathrm{E}+01$ & 107.0 & 103.8 & 112 & 96 & 8 & 8 & 0.71776 \\
\hline $1 \mathrm{E}+02$ & 123.0 & 129.7 & 137 & 122 & 8 & 8 & 0.78049 \\
\hline $1 \mathrm{E}+02$ & 157.0 & 156 & 163 & 148 & 8 & 8 & 0.73376 \\
\hline $1 \mathrm{E}+02$ & 184.0 & 181 & 189 & 173 & 8 & 8 & 0.73043 \\
\hline $2 \mathrm{E}+02$ & 202.0 & 207 & 215 & 199 & 8 & 8 & 0.76040 \\
\hline $2 \mathrm{E}+02$ & 231.0 & 233 & 242 & 225 & 8 & 8 & 0.74805 \\
\hline $2 \mathrm{E}+02$ & 264.0 & 259 & 268 & 250 & 9 & 9 & 0.72727 \\
\hline
\end{tabular}




\begin{tabular}{|c|c|c|c|c|c|c|c|}
\hline \multicolumn{8}{|c|}{ DETECTION LIMITS ACCORDING TO HUBAUX AND VOS } \\
\hline \multirow{4}{*}{$\begin{array}{c}\text { *_*TITLE: } \\
\text { INPUTS } \\
\text { NEEDED: }\end{array}$} & & DET LIM & 1.378 \\
\hline & & & & & 4-sec-butylphenol calibration on RP HPLC @ 205 nm & QUANT LM & 2.789 \\
\hline & \multicolumn{5}{|c|}{ 1. CALIBRATION POINTS STARTING AT X11 AND Y11 } & Intercept, a & 41.267 \\
\hline & \multirow{2}{*}{\multicolumn{2}{|c|}{$\begin{array}{l}\text { : 2. t FOR UPPER CURVE } \\
\text { 3. t FOR LOWER }\end{array}$}} & 1.86 & 95.00 & $\%$ CONFID & St Dev a & 42.631 \\
\hline & & & 1.86 & 95.00 & $\%$ CONFID & Slope, $\mathbf{b}$ & 67.962 \\
\hline & \multicolumn{5}{|c|}{ 4. REGRESSION OUTPUT TO J1. } & St Dev b & $\mathbf{0 . 5 5 9}$ \\
\hline CROSSES? & YES & Area at $\mathrm{Q}$ & ant Limit & 230.8 & & R Squared & 0.99946 \\
\hline \multicolumn{3}{|c|}{ CALIBRATION POINTS } & \multicolumn{2}{|c|}{ ERROR LIMIT CURVES } & \multicolumn{2}{|c|}{ INCREMENTS } & \\
\hline CONC-X & RESP-Y & CALC Y & UPPER Y & LOWER Y & UP INC & LOW INC & conc/resp \\
\hline $8 \mathrm{E}+00$ & 593.0 & 612.1 & 702 & 522 & 90 & 90 & 0.01417 \\
\hline $2 \mathrm{E}+01$ & 1204.0 & 1183.0 & 1270 & 1096 & 87 & 87 & 0.01395 \\
\hline $3 \mathrm{E}+01$ & 1782.0 & 1753.9 & 1839 & 1669 & 85 & 85 & 0.01414 \\
\hline $3 \mathrm{E}+01$ & 2319.0 & 2324.8 & 2408 & 2241 & 84 & 84 & 0.01449 \\
\hline $4 \mathrm{E}+01$ & 2879.0 & 2895.7 & 2979 & 2812 & 83 & 83 & 0.01459 \\
\hline $5 \mathrm{E}+01$ & 3451.0 & 3467 & 3550 & 3383 & 84 & 84 & 0.01460 \\
\hline $6 \mathrm{E}+01$ & 4089.0 & 4037 & 4122 & 3952 & 85 & 85 & 0.01438 \\
\hline $7 \mathrm{E}+01$ & 4548.0 & 4608 & 4695 & 4521 & 87 & 87 & 0.01478 \\
\hline $8 \mathrm{E}+01$ & 513 & 5179 & 5269 & 5089 & 90 & 90 & 0.01473 \\
\hline $8 \mathrm{E}+01$ & 5813.0 & 5750 & 5844 & 5656 & 94 & 94 & 0.01445 \\
\hline
\end{tabular}


DETECTION LIMITS ACCORDING TO HUBAUX AND VOS

*_*TITLE: 4-sec-butylphenol calibration on RP HPLC @ 226 nm INPUTS 1. CALIBRATION POINTS STARTING AT X11 AND Y11

\begin{tabular}{|cc} 
DET LIM & 2.329 \\
QUANT LM & 4.656 \\
Intercept, a & $\mathbf{5 1 . 4 6 7}$ \\
St Dev a & $\mathbf{7 3 . 7 6 0}$ \\
Slope, b & $\mathbf{6 9 . 5 4 2}$ \\
& \\
St Dev b & $\mathbf{0 . 9 6 7}$ \\
R Squared & $\mathbf{0 . 9 9 8 4 6}$
\end{tabular}

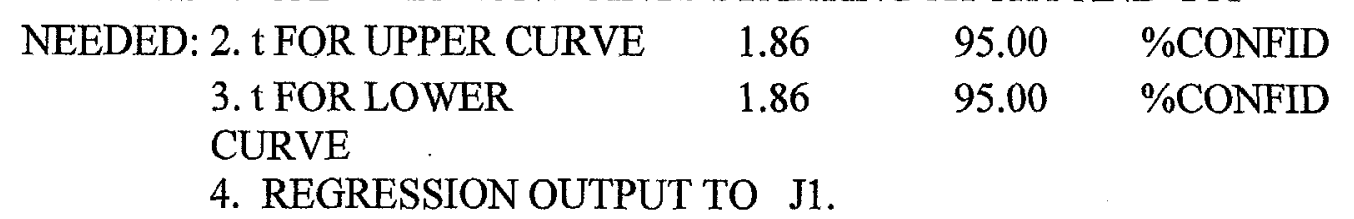

\begin{tabular}{rccccccc}
\multicolumn{2}{c}{ CROSSES? } & YES & \multicolumn{3}{c}{ Area at Quant Limit } & 375.3 & \multicolumn{3}{c}{ R Squared } & $\mathbf{0 . 9 9 8 4 6}$ \\
\multicolumn{2}{c}{ CALIBRATION POINTS } & \multicolumn{3}{c}{ ERROR LIMIT CURVES } & INCREMENTS \\
CONC-X & RESP-Y & CALC Y & UPPER Y & LOWER Y & UP INC & LOW INC & conc/resp \\
$8 \mathrm{E}+00$ & 616.0 & 635.6 & 791 & 480 & 156 & 156 & 0.01364 \\
$2 \mathrm{E}+01$ & 1200.0 & 1219.8 & 1370 & 1069 & 151 & 151 & 0.01400 \\
$3 \mathrm{E}+01$ & 1832.0 & 1803.9 & 1951 & 1657 & 147 & 147 & 0.01376 \\
$3 \mathrm{E}+01$ & 2420.0 & 2388.1 & 2533 & 2243 & 145 & 145 & 0.01388 \\
$4 \mathrm{E}+01$ & 2964.0 & 2972.2 & 3116 & 2828 & 144 & 144 & 0.01417 \\
$5 \mathrm{E}+01$ & 3545.0 & 3556 & 3701 & 3412 & 145 & 145 & 0.01422 \\
$6 \mathrm{E}+01$ & 4240.0 & 4141 & 4287 & 3994 & 147 & 147 & 0.01387 \\
$7 \mathrm{E}+01$ & 4657.0 & 4725 & 4875 & 4574 & 151 & 151 & 0.01443 \\
$8 \mathrm{E}+01$ & 5179.0 & 5309 & 5465 & 5153 & 156 & 156 & 0.01460 \\
$8 \mathrm{E}+01$ & 5990.0 & 5893 & 6055 & 5731 & 162 & 162 & 0.01402
\end{tabular}




\begin{tabular}{|c|c|c|c|c|c|c|c|}
\hline \multicolumn{8}{|c|}{ DETECTION LIMITS ACCORDING TO HUBAUX AND VOS } \\
\hline & \multirow{2}{*}{\multicolumn{5}{|c|}{ 4-sec-butylphenol calibration on RP HPLC @ 254 nm }} & DET LIM & 1.398 \\
\hline \multirow{3}{*}{$\begin{array}{l}\text { *_*TITLE: } \\
\text { INPUT } \\
\text { NEEDED }\end{array}$} & & & & & & QUANT LM & 2.843 \\
\hline & 1. CALIBR & TION POIN & IS STARTII & G AT X11 A & ID Y 11 & Intercept, a & 2.667 \\
\hline & 2. t FOR UP & ER CURVE & 1.860 & 95.000 & $\%$ CONFID & St Dev a & 2.258 \\
\hline & $\begin{array}{l}\text { 3. t FOR LO } \\
\text { CURVE }\end{array}$ & VER & 1.860 & 95.000 & $\%$ CONFID & Slope, b & 3.546 \\
\hline & 4. REGRES & ION OUTPI & T TO J1. & & & St Dev b & 0.030 \\
\hline CROSSES? & YES & Area at $Q$ & aant Limit & 12.7 & & R Squared & 0.99944 \\
\hline CALIBRATI & ION POINTS & & ERROR LIN & IT CURVES & INCREMI & NTS & \\
\hline CONC-X & RESP-Y & CALC Y & UPPER Y & LOWER Y & UP INC & LOW INC & conc/resp \\
\hline $8 \mathrm{E}+00$ & 30.0 & 32.5 & 37 & 28 & 5 & 5 & 0.28000 \\
\hline $2 \mathrm{E}+01$ & 61.0 & 62.2 & 67 & 58 & 5 & 5 & 0.27541 \\
\hline $3 \mathrm{E}+01$ & 92.0 & 92.0 & 97 & 88 & 4 & 4 & 0.27391 \\
\hline $3 E+01$ & 124.0 & 121.8 & 126 & 117 & 4 & 4 & 0.27097 \\
\hline $4 \mathrm{E}+01$ & 153.0 & 151.6 & 156 & 147 & 4 & 4 & 0.27451 \\
\hline $5 \mathrm{E}+01$ & 183.0 & 181 & 186 & 177 & 4 & 4 & 0.27541 \\
\hline $6 \mathrm{E}+01$ & 215.0 & 211 & 216 & 207 & 4 & 4 & 0.27349 \\
\hline $7 \mathrm{E}+01$ & 239.0 & 241 & 246 & 236 & 5 & 5 & 0.28117 \\
\hline $8 \mathrm{E}+01$ & 269.0 & 271 & 276 & 266 & 5 & 5 & 0.28104 \\
\hline $8 \mathrm{E}+01$ & 299.0 & 301 & 306 & 296 & 5 & 5 & 0.28094 \\
\hline
\end{tabular}




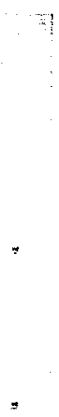




\section{INTERNAL DISTRIBUTION}

1. K. K. Anderson

2. J. F. Birdwell, Jr.

3. P. V. Bonnesen

4. J. L. Collins

5. R. L. Cummins

6. L. H. Delmau

7. R. D. Hunt

8. R. T. Jubin

9. T. E. Kent

10-13. L. N. Klatt

14. D. D. Lee

15. M. P. Maskarinec

16. A. Mattus

17. C. P. McGinnis

18. L. E. McNeese

19. B. A. Moyer

20. F. V. Sloop, Jr.

21-22. R. A. Jenkins

23. J. F. Walker

24. J. S. Watson

25. ORNL Central Research Library

26. Laboratory Records, RC

27. Laboratory Records, OSTI

\section{EXTERNAL DISTRIBUTION}

28. J. T. Carter, Westinghouse Savannah River Company, P.O. Box 616, Buidling 704-3B, Aiken, SC 29808

29. D. Chamberlain, Argonne National Laboratory; Building 205, 9700 South Cass Avenue, Argonne, IL 60439

30. N. F. Chapman, Westinghouse Savannah River Company, P:O. Box 616, Buidling 704-3B, Aiken, SC 29808

31. C. Conner, Argonne National Laboratory, Building 205, 9700 South Cass Avenue, Argonne, IL 60439

32. R. G. Edwards, Westinghouse Savannah River Company, P.O. Box 616, Buidling 704-3B, Aiken, SC 29808

33. S. D. Fink, Westinghouse Savannah River Company, P.O. Box 616, Building 773-A, Aiken, SC 29808 
34. H. D. Harmon, Tank Focus Area Salt Processing Program, P.O. Box 616, Building 704-3N, Aiken, SC 29808

35. R. T. Jones, Westinghouse Savannah River Company, P.O. Box 616, Building 704-3N, Aiken, SC 29808

36. R. A. Leonard, Argonne National Laboratory, Building 205, 9700 South Cass Avenue, Argonne, IL 60439

37. J. W. McCullough, Jr., U.S. Department of Energy, Savannah River Operations Office, Bldg. 704-3N, Aiken, SC 29808

38. J. R. Noble-Dial, U.S. Department of Energy, Oak Ridge Operations Office, P.O. Box 2001, Oak Ridge, TN 37831-8620

39. Michael Norato, Westinghouse Savannah River Company, P.O. Box 616, Building 773-A, Aiken, SC 29808

40. Robert Pierce, Westinghouse Savannah River Company, P.O. Box 616, Building 773-A, Aiken, SC 29808

41. S. N. Schlahta, Tank Focus Area Salt Processing Program, P. O. Box 616, Building 704-3N, Aiken, SC 29808

42. P. C. Suggs, U.S. Department of Energy, Savannah River Operations Office, P.O. Box A, Building 704-3N, Aiken, SC 29808

43. W. L. Tamosaitis, Westinghouse Savannah River Company, P.O. Box 616, Building 773-A, Aiken, SC 29808

44. M. Thompson, Westinghouse Savannah River Company, P.O. Box 616, Building 773-A, Aiken, SC 29808

45. T. A. Todd, Idaho National Engineering \& Environmental Laboratory, Building 637, MS-5218, Idaho Falls, ID 834415-5218

46. G. Vandegrift, Argonne National Laboratory, Building 205, 9700 South Cass Avenue, Argonne, IL 60439

47. Doug Walker, Westinghouse Savannah River Company, P.O. Box 616, Building 773-A, Aiken, SC 29808

48. Dennis Wester, Westinghouse Savannah River Company, P.O. Box 616, Building 773-A, Aiken, SC 29808 
49. W. R. Wilmarth, Westinghouse Savannah River Company, P.O. Box 616, Building 773-A, Aiken, SC 29808

50. Tanks Focus Area Technical Team, c/o B. J. Williams, Pacific Northwest National Laboratory, P.O. Box 999, MSIN K9-69, Richland, WA 99352

51. Tanks Focus Area Field Lead, c/o T. P. Pietrok, U.S. Department of Energy, Richland Operations Office, P.O. Box 550, K8-50, Richland, WA 99352

52. Tanks Focus Area Headquarters Program Manager, c/o K. D. Gerdes, DOE Office of Science and Technology, 19901 Germantown Rd., 1154 Cloverleaf Building, Germantown, MD 20874-1290

53. Tom White, Westinghouse Savannah River Company, P.O. Box 616, Building 773-A, Aiken, SC 29808 


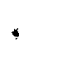

